\author{
UNIVERSIDADE DE SÃO PAULO \\ ESCOLA DE ENGENHARIA DE SÃO CARLOS
}

\begin{abstract}
MÉTODO DE ENSAIO PARA A DETERMINAÇÃO DA RESISTÊNCIA AO CISALHAMENTO EM ELEMENTOS ESTRUTURAIS DE MADEIRA DE Pinus spp.
\end{abstract}





\title{
MÉTODO DE ENSAIO PARA A DETERMINAÇÃO DA RESISTÊNCIA AO CISALHAMENTO EM ELEMENTOS ESTRUTURAIS DE MADEIRA DE Pinus spp.
}

\author{
Versão Corrigida
}

Dissertação apresentada ao Programa de Ciência e Engenharia de Materiais, da Universidade de São Paulo para a obtenção do título de Mestre em Ciências.

Área de concentração: Desenvolvimento, Caracterização e Aplicação de Materiais

Orientador: Carlito Calil Junior

São Carlos 
AUTORIZO A REPRODUÇÃO E DIVULGAÇÃO TOTAL OU PARCIAL DESTE TRABALHO, POR QUALQUER MEIO CONVENCIONAL OU ELETRÔNICO, PARA FINS DE ESTUDO E PESQUISA, DESDE QUE CITADA A FONTE.

$5237 \mathrm{~m}$ Santos, Caio Victor Fernandes dos

Método de ensaio para a determinação da resistência ao cisalhamento em elementos estruturais de madeira de Pinus spp. / Caio Victor Fernandes dos Santos; orientador Carlito Calil Junior. -- São Carlos, 2016.

Dissertação (Mestrado em Engenharia de Materiais e Área de concentração Desenvolvimento, Caracterização e Aplicação de Materiais). -- Escola de Engenharia de São Carlos da Universidade de São Paulo, 2016.

1. Madeira. 2. Resistência ao cisalhamento. 3. Caracterização. I. Título. 


\section{FOLHA DE JULGAMENTO}

\section{Candidato: CAIO VICTOR FERNANDES DOS SANTOS}

Título da dissertação: "Método de ensaio para a determinação da resistência ao cisalhamento em elementos estruturais de madeira de Pinus spp."

Data da defesa: 28.07.2016

Comissão Julgadora:

Resultado:

Prof. Titular Carlito Calil Junior (Orientador)

APRON BOOO

(Escola de Engenharia de São Carlos/EESC)

Prof. Dr. Antonio Alves Dias

A PROQ

(Escola de Engenharia de São Carlos/EESC)

Prof. Dr. Julio Cesar Molina

Aprovatoo

(Universidade Estadual Paulista "Júlio de Mesquita Filho"/UNESP - Itapeva)

Coordenador do Programa de Pós-Graduação em Ciências e Engenharia de Materiais:

Prof. Associado Antonio José Felix de Carvalho

Presidente da Comissão de Pós-Graduação:

Prof. Associado Luís Fernando Costa Alberto 

Aos meus familiares e amigos, pelo carinho, companheirismo e dedicação. 



\section{AGRADECIMENTOS}

Agradeço primeiramente a Deus, pela minha vida, saúde e família.

Quero agradecer em especial meus pais, Aguinaldo e Josi, sem os quais eu nunca teria imaginado estar aqui. Agradeço também pelo privilégio de ter uma irmã linda, Barbara, que sempre me recebe com carinho, amor e paciência.

Agradeço ao professor que tornou este trabalho possível, pela confiança em mim depositada, pelos ensinamentos e pela excelente orientação, Prof. Dr. Carlito Calil Junior.

Aos professores, Francisco Antônio Rocco Lahr e Antônio Alves Dias, amigos e companheiros de laboratório, por toda ajuda.

Agradeço aos técnicos do Laboratório de Madeiras e Estruturas de Madeira (LaMEM), pelo auxílio na execução dos ensaios realizados nesta pesquisa, para que tudo fosse concluído em tempo hábil.

Aos meus amigos, que não são poucos, faltariam palavras para demonstrar o quanto sou grato a vocês. Cada minuto ao lado de vocês me torna uma pessoa mais preparada para a vida.

Universidade de São Paulo (USP), Escola de Engenharia de São Carlos (EESC), representada por seus professores e funcionários, agradeço pelo suporte, prontidão nos esclarecimentos, disponibilidade de serviços e tecnologias a mim oferecidas durante todo o mestrado.

A todos que contribuíram para a realização deste trabalho.

Mais uma vez, Obrigado! 



\section{RESUMO}

SANTOS, C. V. F. Método de ensaio para a determinação da resistência ao cisalhamento em elementos estruturais de madeira de Pinus spp. 2016. 82 p. Dissertação (Mestrado em Ciência e Engenharia de Materiais) - Escola de Engenharia de São Carlos, Universidade de São Paulo, São Carlos, 2016.

Tendo em vista a inserção das madeiras de reflorestamento nos projetos estruturais, têm-se a necessidade de realizar ensaios de caracterização que sejam mais adequados. $\mathrm{O}$ documento normativo ABNT NBR 7190:1997 padroniza os ensaios mecânicos para projetos de estruturas de madeira no Brasil. Estes ensaios são realizados a partir de testes em corpos de prova de pequenas dimensões e isentos de defeitos. Porém, a incidência de defeitos ocorre nas peças utilizadas em estruturas e, por isso, podem ocorrer diferenças consideráveis de resistência entre os corpos de prova isentos de defeitos e os corpos de prova estruturais. Os documentos normativos ASTM ISO 13910:2005 e EUROCODE EN 408:2010 estabelecem um padrão de ensaios com a utilização de peças de tamanho estrutural. Portanto, o presente estudo busca definir as possíveis diferenças entre os ensaios realizados de acordo com ambas as normas. Foram realizados ensaios para a determinação da resistência ao cisalhamento paralelo às fibras com a madeira de Pinus spp., de acordo com as normas ABNT NBR 7190:1997 e ASTM ISO 13910:2005. Devido a problemas de colagem não foram concluídos ensaios segundo a norma EUROCODE EN 408:2010. A análise dos resultados permitiu perceber que a utilização da norma ABNT NBR 7190:1997 pode indicar dados inexatos em relação à real resistência do material em questão.

Palavras Chave: madeira, resistência ao cisalhamento, caracterização, normalização. 



\begin{abstract}
SANTOS, C. V. F. Test method for the determination of shear strength in timber structural elements in Pinus spp. 2016. 82 p. Master's Dissertation (Master in Science and Engineering of Materials) - School of Engineering of São Carlos, University of São Paulo, 2016
\end{abstract}

Considering the insertion of reforesting woods in structural designs that has the need to perform characterization tests which are more suitable. The normative document ABNT NBR 7190:1997 standardizes the mechanical tests for wooden structures projects. These tests are carried out from tests in small specimens and no defects. However, the incidence of defects occur in parts used in structures, therefore, can occur considerable differences in resistance between the samples free of defects and structural specimens. The normative document ASTM ISO 13910:2005 and EUROCODE EN 408:2010 establishes a test pattern with the use of structural specimens. Therefore, the present study seeks to define the possible differences between the tests performed in accordance with both standards. Assays were performed to determine the shear strength parallel fibers of Pinus spp., according to ABNT NBR7190:1997 and ASTM ISO 13910:2005. There was an attempt to hold up tests following the premises of EUROCODE EN 408:2010. The results allowed the perception of evidence that the use of ABNT NBR 7190 standard may indicate infidels data regarding the real strength of the material in question.

Keywords: timber, shear strength, characterization, standardization. 



\section{LISTA DE FIGURAS}

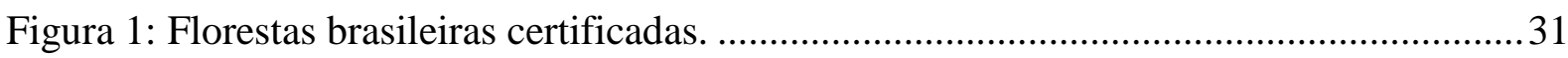

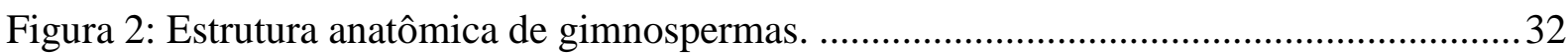

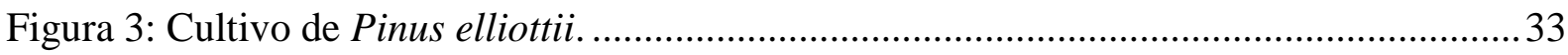

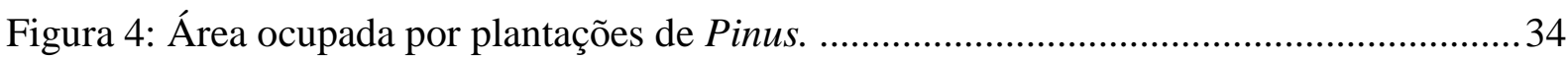

Figura 5: Usos temporários da madeira na construção civil................................................. 35

Figura 6: Usos definitivos da madeira na construção civil................................................... 36

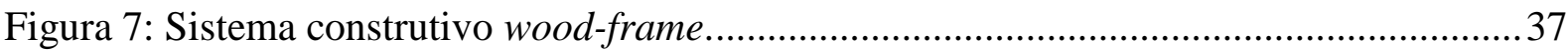

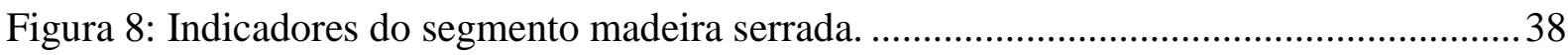

Figura 9: Detalhe da presença de nós em peças estruturais de madeira................................. 39

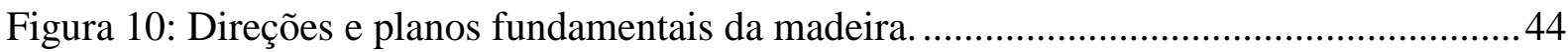

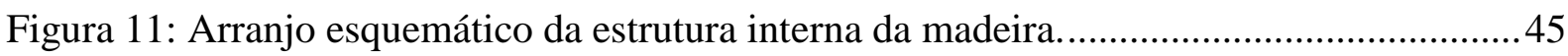

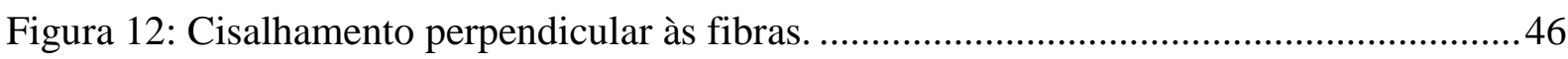

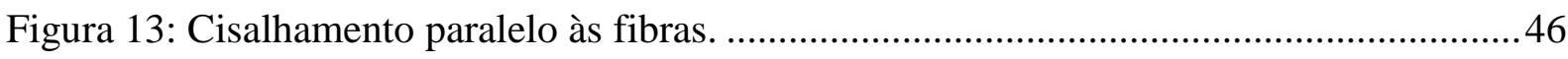

Figura 14: Cisalhamento perpendicular aos anéis de crescimento - rolling shear...................46

Figura 15: Corpo de prova para o ensaio de cisalhamento...................................................... 48

Figura 16: Arranjo de ensaio para a determinação da resistência ao cisalhamento. ................ 49

Figura 17: Seções de trabalho em função da orientação de corte da madeira..........................49

Figura 18: A - Corte perpendicular; e B - Corte tangencial aos anéis de crescimento..............50

Figura 19: Esquema de ensaio para medir a resistência ao cisalhamento paralelo às fibras. ...51

Figura 20: Dimensões das placas metálicas utilizadas no carregamento. ...............................52

Figura 21: Distribuição de esforços durante método de ensaio ASTM ISO 13910:2005........53

Figura 22: Corpo de prova de madeira fixado nas placas metálicas. .......................................55

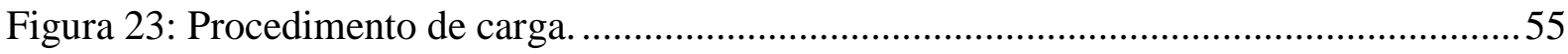

Figura 24: Orientação de corte da madeira em relação aos anéis de crescimento.....................56

Figura 25: Orientação de corte tangencial aos anéis de crescimento da madeira.....................57

Figura 26: Orientação de corte inclinada $\left(45^{\circ}\right)$ em relação aos anéis de crescimento...............57

Figura 27: Lote de madeira de Pinus spp. fornecidos pela Berneck S.A. ............................... 61

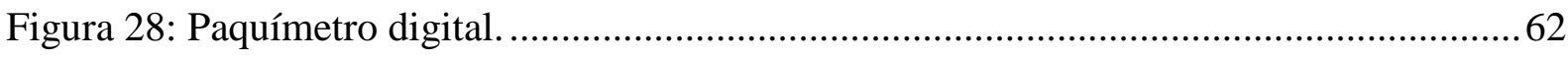

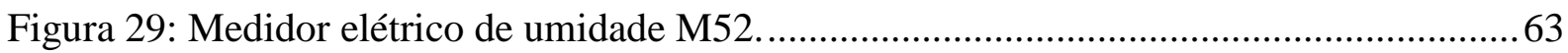

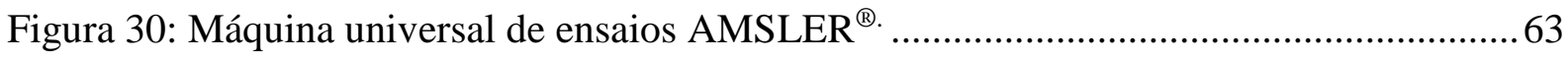

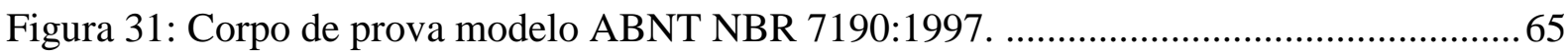


Figura 32: Arranjo de ensaio segundo a ABNT NBR 7190:1997. 65

Figura 33: Detalhe da ruptura em corpo de prova no modelo da ABNT NBR 7190:1997. .... 66

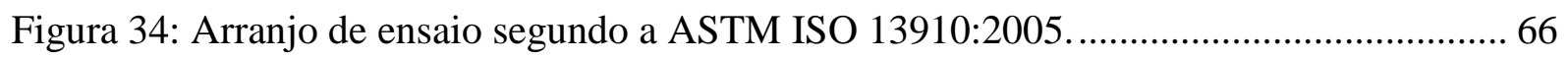

Figura 35: Detalhes de algumas rupturas em corpos de prova ASTM ISO 13910:2005......... 67

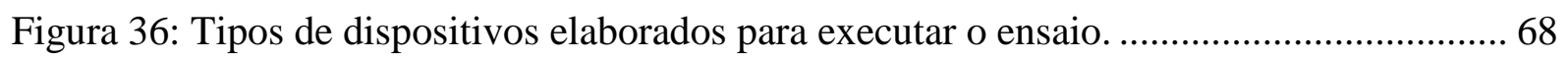

Figura 37: Arranjo de ensaio segundo o EUROCODE EN 408:2010 ................................... 68

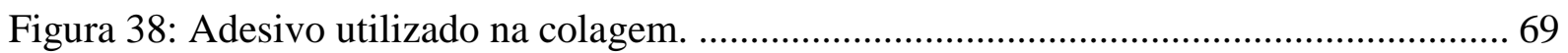

Figura 39: Detalhe do destacamento na interface adesivo/dispositivo metálico. .................... 69

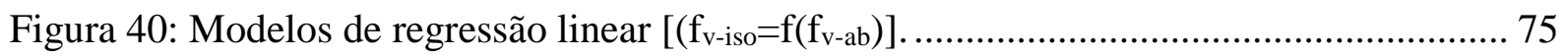

Figura 41: Modelos de regressão linear $\left[\left(f_{\mathrm{v}-\text { iso }}=\mathrm{f}\left(\mathrm{f}_{\mathrm{v}-\mathrm{ab}}\right)\right]\right.$ com a exclusão dos outliers.............. 76 


\section{LISTA DE TABELAS}

Tabela 1: Áreas estimadas de florestas no Brasil (2012).....................................................29

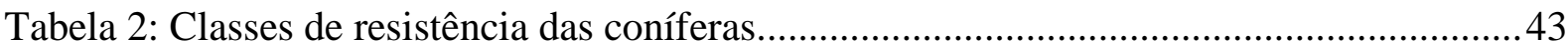

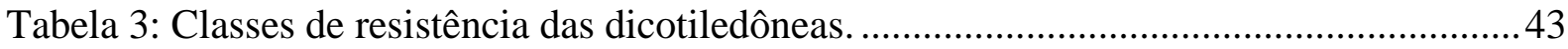

Tabela 4: Modelos de regressão utilizados na estimativa de fv-iso. ....................................... 70

Tabela 5: Estatísticas descritivas dos valores da resistência ao cisalhamento. ........................ 73

Tabela 6: Valores característicos de resistência ao cisalhamento paralelo às fibras................74

Tabela 7: Modelos de regressão utilizados na estimativa dos valores da resistência ao cisalhamento na flexão em função dos valores da resistência ao cisalhamento direto 



\section{LISTA DE SIGLAS E ABREVIATURAS}

ABNT - Associação Brasileira de Normas Técnicas

ABRAF - Associação Brasileira de Produtores de Florestas Plantadas

ASTM - American Society for Testing and Materials

Cerflor - Programa Nacional de Certificação Florestal

EESC - Escola de Engenharia de São Carlos

EMBRAPA - Empresa Brasileira de Pesquisas Agropecuárias

FAO - Organização das Nações Unidas para a Agricultura e Alimentação

FSC - Forest Stewardship Council

IBÁ - Industria Brasileira de Árvores

IBGE - Instituto Brasileiro de Geografia e Estatística

ISO - International Organization for Standardization

LaMEM -Laboratório de Madeiras e de Estruturas de Madeira

NBR - Norma Brasileira Registrada

PEFC - Programme for the Endorsement of Forest Certification Schemes

SET - Departamento de Engenharia de Estruturas

SFB - Serviço Florestal Brasileiro

SNIF - Sistema Nacional de Informações Florestais

USP - Universidade de São Paulo 



\section{SUMÁRIO}

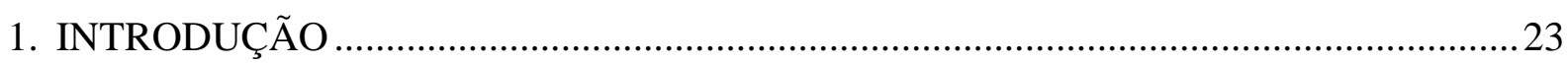

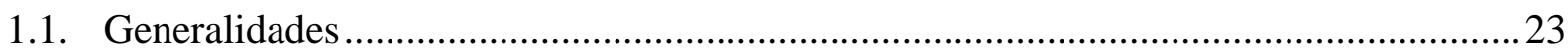

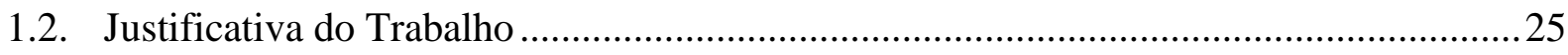

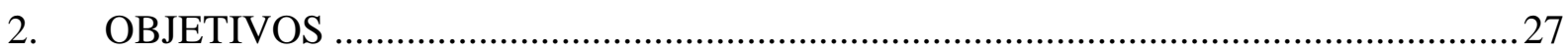

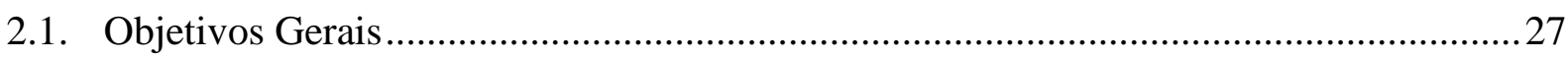

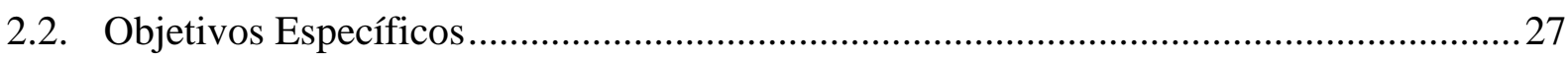

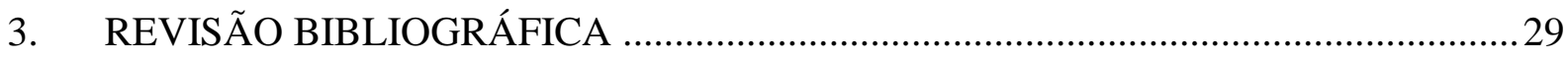

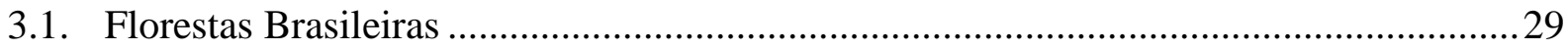

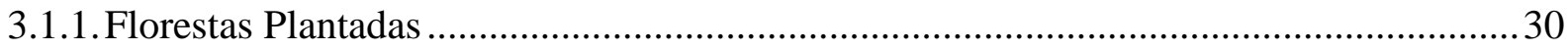

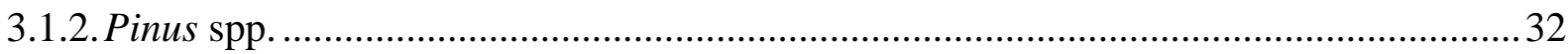

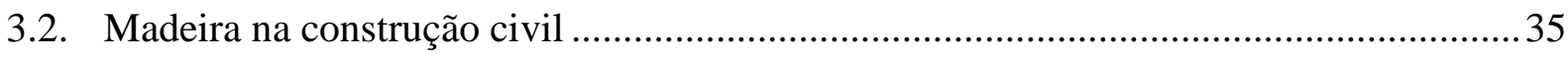

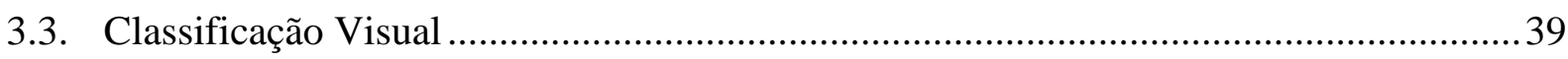

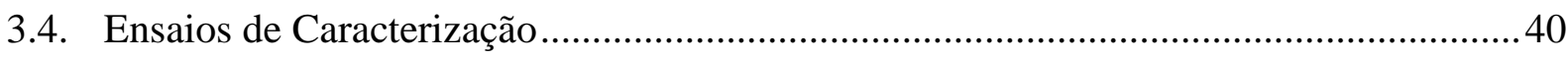

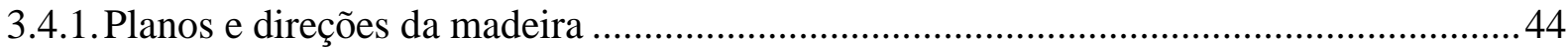

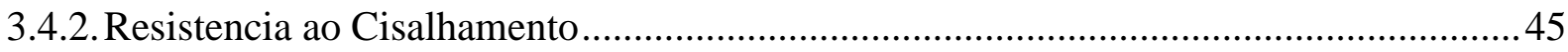

3.5. Normas vigentes e métodos de ensaio .......................................................................4 47

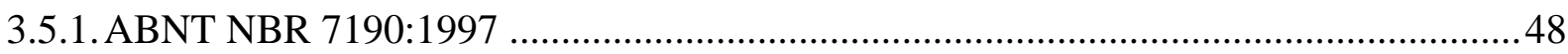

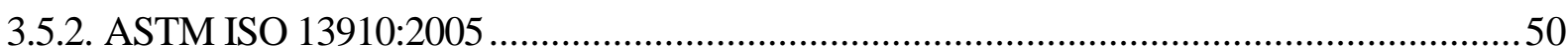

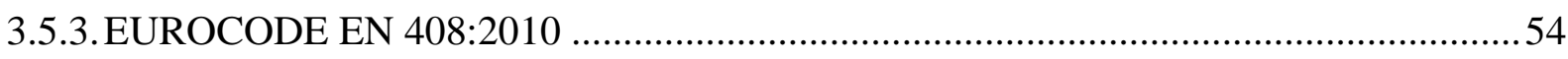

3.6. Contribuições de outros pesquisadores .................................................................57

3.7. Principais conclusões da revisão bibliográfica …………………………………….......59

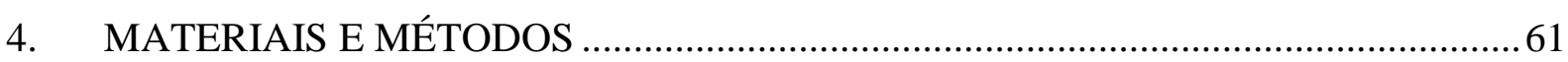

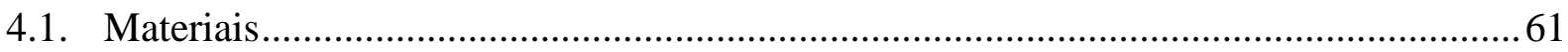

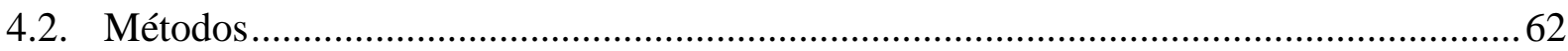

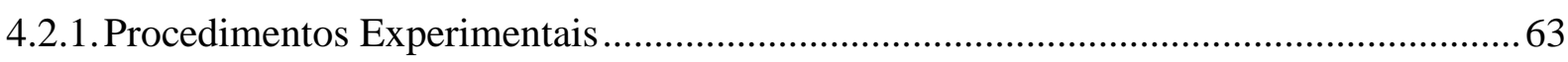

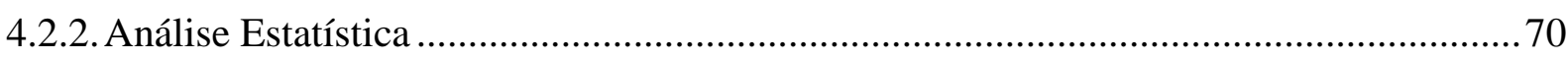

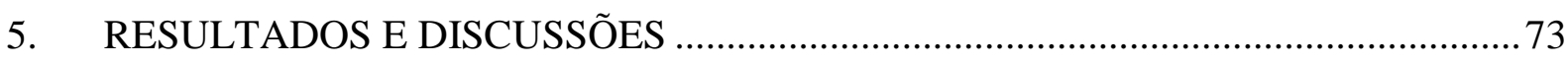

5.1. Apresentação dos Resultados Experimentais ....................................................................73

6. CONCLUSÕES E SUGESTÕES PARA TRABALHOS FUTUROS ............................77

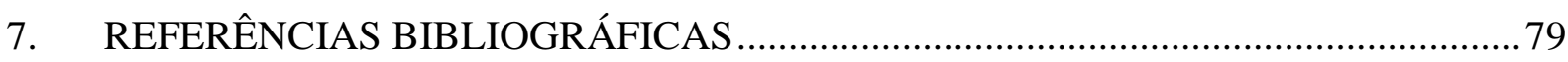





\section{INTRODUÇÃO}

\subsection{Generalidades}

A madeira é um compósito natural formado basicamente por polímeros: a celulose e as hemiceluloses. As quantidades de cada polímero variam conforme a espécie de madeira. As coníferas são formadas por 48 a $56 \%$ de celulose e 23 a $26 \%$ de hemicelulose, enquanto as dicotiledôneas são compostas por 46 a $48 \%$ de celulose e 19 a $28 \%$ de hemicelulose, (CALIL JUNIOR; R. LAHR; DIAS, 2003). Estes polímeros formam cadeias de moléculas longas e repetitivas, que fornecem ao material características físico-mecânicas relevantes, como uma alta relação resistência versus peso especifico. Além destes polímeros, o material apresenta lignina e extrativos, que são macromoléculas e sais respectivamente (CHRISTOFORO et al., 2014; CORADIN \& CAMARGOS, 2002).

Esse material está presente no cotidiano das pessoas nas mais diversas formas de utilização. Além dos usos tradicionais como fabricação de móveis, confecção de esquadrias, celulose, papel e suas aplicações, tem-se os derivados da resina, como: tintas, vernizes, colas, graxas, esmaltes, ceras, adesivos, óleos, produtos de limpeza e muito mais. Portanto, sua versatilidade é evidenciada desde a geração de energia calorífica até o uso como material construtivo.

É um material fibroso, originário do tecido vegetal proveniente do lenho de árvores, com características intrínsecas, formado pela reação básica da fisiologia das plantas: a fotossíntese. Por isso é tido como um material renovável, com papel importante no ciclo do carbono e também no âmbito da sustentabilidade. Para produzir aproximadamente $1 \mathrm{~m}^{3}$ de madeira, a árvore assimila e armazena cerca de 1 tonelada de $\mathrm{CO}_{2}$. Paralelamente a isso, ainda produz de 300 a $400 \mathrm{~kg}$ de oxigênio. (SANDOZ, 2003).

A demanda por madeira serrada ainda vem sendo atendida com matérias-primas provenientes de florestas nativas do Norte e Centro-Oeste do País. No entanto, as florestas artificiais, sobretudo as do gênero Pinus, constituem uma alternativa para o abastecimento do mercado. Seu emprego é favorecido pelos baixos custos de implantação e exploração. Ainda assim, considera-se que a utilização de peças serradas de Pinus, na construção civil, não atinge um percentual mais significativo pela carência de divulgação das informações acerca de suas propriedades. 
A gestão sustentável do recurso florestal é fundamental, pois o desmatamento acarreta graves danos ambientais, e por isso a exploração comercial dos produtos florestais precisa ser feita de maneira controlada, contribuindo para o crescimento econômico. Com isso a silvicultura assume um papel importante para o setor madeireiro.

Em média, uma pessoa utiliza $0,5 \mathrm{~m}^{3}$ de madeira por ano. Para tal, cada metro cúbico precisa dispor de $25 \mathrm{~m}^{2}$ de floresta plantada. Ou seja, aos 80 anos, esta mesma pessoa, terá consumido $1000 \mathrm{~m}^{2}$ de floresta. Considerando toda a população do planeta, o consumo total de madeira é de 3,5 bilhões de $\mathrm{m}^{3} /$ ano. Tais quantidades podem ser produzidas preservando as matas nativas devido ao crescente incentivo, desde o início do século $\mathrm{XX}$, aos plantios renováveis (IBÁ, 2015).

Apoiado na demanda por produtos à base de madeira o setor florestal se tornou a principal fonte de renda de alguns polos do Brasil, sendo eles a região Sul e parte da região Sudeste, que se caracterizam pelas grandes áreas de florestas plantadas, principalmente com os gêneros Eucalyptus e Pinus. (ABRAF, 2013).

A utilização da madeira como elemento estrutural requer conhecimento prévio de suas propriedades, principalmente, as físicas e as mecânicas, que interferem diretamente no dimensionamento de elementos estruturais. Assim, nos projetos de estruturas de madeira devese buscar compatibilidade com as solicitações mecânicas impostas, sempre levando em consideração a segurança (MOLINA \& CALIL JUNIOR, 2011).

A variabilidade, ou variação nas propriedades, é bastante comum em todos os materiais. Na madeira, um material produzido pela natureza, não poderia ser diferente, estando a árvore suscetível, desde o plantio até a colheita, a muitos fatores que influenciam em suas propriedades. Segundo Karlsen et al. (1967), as variações nas características da madeira são resultado das condições climáticas, composição e umidade do solo, espaçamento, tipo de manejo aplicado, posição da árvore em relação ao relevo, entre outros, de modo que árvores da mesma espécie podem ter características com diferenças significativas.

Atualmente, os ensaios de caracterização das propriedades mecânicas são realizados segundo a ABNT NBR 7190:1997, com pequenos corpos de prova isentos de defeitos. Devese levar em consideração que em serviço, ocorrem, principalmente em madeiras de florestas plantadas defeitos como: nós, fissuras, empenamentos, desvios de grã nos elementos, o que acarreta em uma diminuição nos valores reais de resistência das peças (OLIVEIRA, 2007).

Os defeitos de crescimento incidem com grande assiduidade nas madeiras de Pinus. Paralelo a isto, têm-se a necessidade de avaliar as propriedades de resistência e rigidez através de métodos que considerem estas imperfeições. Para tanto, deve-se recorrer aos métodos de 
ensaio com corpos de prova de tamanho real, como é o caso do documento normativo ASTM ISO 13910:2005 e o código europeu de normas EUROCODE EN 408:2010, que preconizam ensaios com corpos de prova estruturais suscetíveis a presença de defeitos.

Neste trabalho foi analisada a resistência ao cisalhamento paralelo às fibras segundo as normas brasileira, norte americana e europeia. Esta solicitação pode ocorrer em ligações em estruturas de madeira bem como na flexão de elementos estruturais. Portanto, a resistência ao cisalhamento é de grande importância em madeiras aplicadas na fabricação de estruturas como tesouras e treliças para coberturas, por exemplo.

\subsection{Justificativa do Trabalho}

Visto que os ensaios realizados no Brasil seguem o documento normativo ABNT NBR 7190:1997, e que na época as espécies de madeira estudadas eram provenientes de florestas tropicais, foi realizada uma vasta avaliação, tanto teórica como experimental, em madeiras de reflorestamento, com o intuito de aproximar os resultados obtidos às reais exigências impostas em estruturas atuais.

O estudo abrangeu, fundamentalmente, o cisalhamento que ocorre entre as camadas da madeira, base para o estudo do cisalhamento na flexão usado no documento normativo ASTM ISO 13910:2005. Apresenta-se ainda a contribuição de outros pesquisadores, bem como os principais métodos de ensaio utilizados.

Como resultado mais relevante deste trabalho, apresenta-se uma proposta de método de ensaio para determinação da resistência ao cisalhamento de elementos estruturais de madeira proveniente de florestas plantadas, realizando ensaios em peças estruturais, analisando a variabilidade, diferentemente dos procedimentos prescritos na norma brasileira, que se adapta bem a madeiras tropicais, usualmente isentas de defeitos. 


\section{OBJETIVOS}

\subsection{Objetivos Gerais}

Este trabalho tem como objetivo geral aprofundar um estudo sobre métodos de ensaio para a determinação da resistência da madeira ao cisalhamento. Trabalhou-se com documentos normativos ABNT NBR 7190:1997, ASTM ISO 13910:2005 e EUROCODE EN 408:2010, com a finalidade de estabelecer uma proposta de método de ensaio para a determinação da resistência da madeira a esta solicitação.

\subsection{Objetivos Específicos}

Este trabalho tem como objetivos específicos:

- Observar as diferenças entre as formas de determinação da resistência ao cisalhamento da atual norma brasileira e as normas de outros países com tradição na construção com madeira.

- Revisar a bibliografia existente com o objetivo de verificar os procedimentos experimentais para a determinação da resistência ao cisalhamento nos principais documentos normativos de outros países.

- Realizar uma experimentação sob orientação dos mesmos documentos, com a finalidade de estabelecer a resistência ao cisalhamento de uma forma mais realista.

- Analisar os resultados obtidos e, baseado nos mesmos, propor ou não a adoção de um método de ensaio para avaliação da resistência ao cisalhamento paralelo às fibras em elementos estruturais de madeira para a documentação normativa nacional. 


\section{REVISÃO BIBLIOGRÁFICA}

Os principais conceitos necessários para o entendimento do tema desta pesquisa são abordados neste capitulo, sendo: a importância da utilização da madeira, as características do material proveniente de florestas plantadas, os procedimentos para caracterização da madeira, os documentos normativos que tratam da resistência ao cisalhamento e pesquisas recentes que mostram o que está sendo trabalhado no Brasil e no mundo sobre o objeto de estudo deste trabalho.

\subsection{Florestas Brasileiras}

Segundo o Instituto Brasileiro de Geografia e Estatística (IBGE), o Brasil abriga seis tipos de biomas. Bioma é um conjunto de vida, vegetal e animal, constituído pelo agrupamento de tipos de vegetação identificáveis e condições climáticas similares, o que resulta em uma diversidade biológica própria. Os Biomas encontrados no Brasil são: Amazônia, Cerrado, Mata Atlântica, Caatinga, Pampa e Pantanal (IBGE, 2009).

A Organização das Nações Unidas para a Agricultura e Alimentação (FAO) conceitua florestas como sendo: “[...] área medindo mais de 0,5 hectares com árvores maiores que 5 metros de altura e cobertura de copa superior a 10\%, ou árvores capazes de alcançar estes parâmetros in situ. Isso não inclui terra que está predominantemente sob uso agrícola ou urbano".

O Serviço Florestal Brasileiro (SFB) disponibiliza dados de 2012, onde o Brasil é classificado como um país florestal com 463 milhões de hectares (54,4\% do seu território) de florestas naturais e plantadas. Estes números são apresentados abaixo (Tabela 1) e representam a segunda maior área de florestas do mundo, atrás apenas da Rússia.

Tabela 1: Áreas estimadas de florestas no Brasil (2012).

\begin{tabular}{cccc}
\hline \hline Tipo de Floresta & Área total (ha) & \% das Florestas & \% da área do Brasil \\
\hline Florestas Naturais & 456.083 .955 & 98,45 & 53,56 \\
\hline Florestas Plantadas & 7.185 .943 & 1,55 & 0,84 \\
\hline Total & $\mathbf{4 6 3 . 2 6 9 . 8 9 8}$ & $\mathbf{1 0 0}$ & $\mathbf{5 4 , 4}$ \\
\hline \hline
\end{tabular}




\subsubsection{Florestas Plantadas}

A silvicultura teve início no Brasil no início do século passado, com o estabelecimento dos plantios florestais com espécies exóticas para substituição da madeira das florestas nativas de difícil reposição. As principais espécies trazidas para o Brasil foram os eucaliptos, introduzidos pela Companhia Paulista de Estradas de Ferro em 1904, e as coníferas (Pinus), pela Companhia Melhoramentos de São Paulo em 1922. A tecnologia desenvolvida neste período encontra-se fortalecida pelas indústrias florestais brasileiras até os dias atuais (PEREIRA et al., 2000).

Segundo consta no anuário estatístico do Ibá (Industria Brasileira de Árvores), no ano de 2014, as áreas ocupadas pelo setor brasileiro de florestas plantadas representam 7,74 milhões de hectares, o que corresponde a aproximadamente 1\% do território nacional. Este setor é responsável por $91 \%$ de toda a madeira produzida para fins industriais no País - os demais 9\% vem de florestas nativas legalmente manejadas (IBÁ, 2015).

Atualmente no Brasil existe um grande número de florestas plantadas de madeiras de diferentes espécies de Pinus e Eucalyptus. Também tem ganhado destaque o aumento do número de florestas plantadas de híbridos, com novas tecnologias para aumentar a produtividade, combinando melhoramento genético de sementes e clonagem de espécies florestais visando melhorar suas propriedades mecânicas.

De acordo com Valverde et al. (2004), o grande crescimento das plantações florestais se deve às condições favoráveis encontradas no país, como clima, solo, extensão territorial, mão de obra, infraestrutura e capacidade gerencial produtiva, impulsionando a economia e aumentando o nível de exportações do setor.

Dentre as espécies mais cultivadas, os plantios de Eucaliptos representaram cerca de $75 \%$, e os plantios de Pinus 25\% da área total de florestas plantadas em 2012. A madeira proveniente destes milhões de hectares é processada quase que totalmente dentro do Brasil (ABRAF, 2013).

Do total de árvores plantadas no Brasil, 4,88 milhões de hectares (63\%) são certificados por organizações independentes, como o Forest Stewardship Council (FSC) e o Programme for the Endorsement of Forest Certification Schemes (PEFC), sendo este último representado no pelo Programa Nacional de Certificação Florestal (Cerflor). Da área certificada, 1,70 milhões de hectares (35\%) são certificados conjuntamente pelos programas FSC e Cerflor/PEFC, 2,60 milhões de hectares (53\%) são certificados exclusivamente pelo FSC e outros 0,58 milhões de hectares (12\%) exclusivamente pelo Cerflor/PEFC, como mostra a Figura 1. 


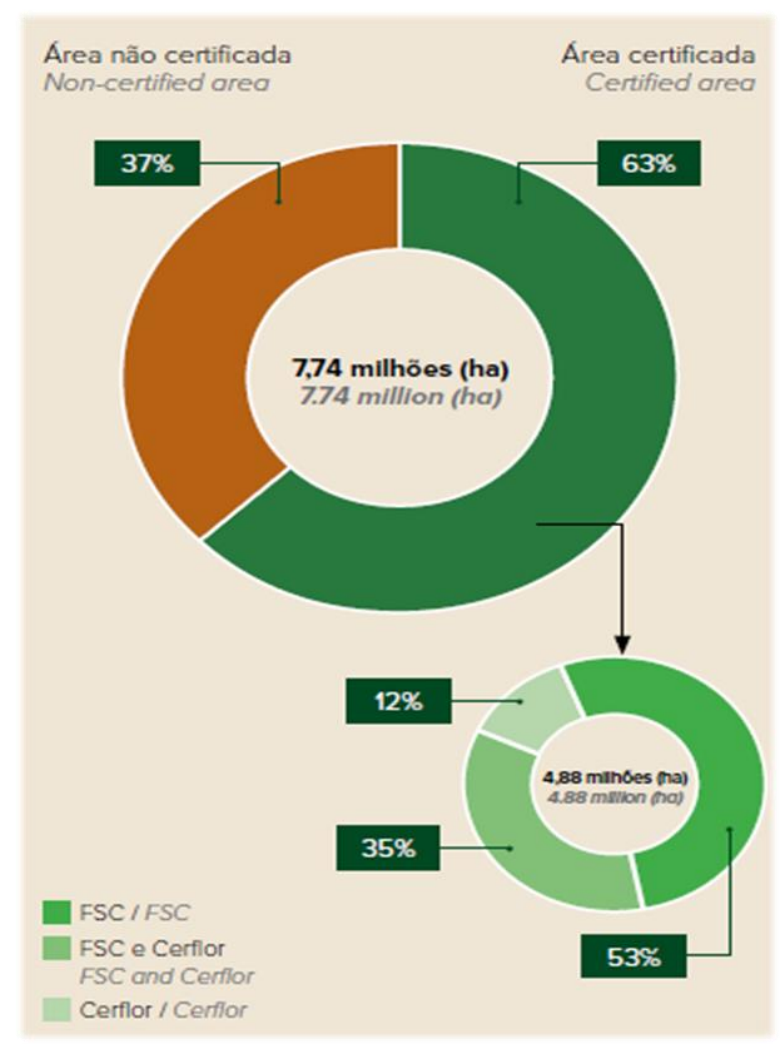

Figura 1: Florestas brasileiras certificadas.

Fonte: IBÁ (2015).

Os principais produtos da atividade madeireira são: celulose, para diversos tipos de papel - para embalagens, papel cartão, para fins sanitários (tissue), imprensa e especiais painéis de madeira reconstituída, pisos laminados, painéis compensados, móveis, demais produtos sólidos de madeira, carvão vegetal e outras biomassas para fins energéticos.

As empresas do setor intensificaram os investimentos para o desenvolvimento de bioprodutos para atender a demanda futura da população por alimento, água, terra e energia . Uma das ferramentas adotadas pelas empresas do setor florestal para demonstrar a sustentabilidade da cadeia produtiva de árvores plantadas e o comprometimento com as questões ambientais e sociais e a certificação florestal (IBÁ, 2015).

As pesquisas acerca das propriedades de resistência e rigidez utilizando madeira são importantes para os fins que possam ser destinados, entre eles a construção civil e a indústria. A madeira é uma matéria-prima de formação contínua, apta a uma grande diversidade de usos, seja ela proveniente de florestas nativas ou advinda de florestas artificiais oriundas de reflorestamentos (STAMATO, 1998). 


\subsubsection{Pinus spp.}

Existem duas vertentes naturais de classificação taxonômicas, as Angiospermas e Gimnospermas. A segunda, que engloba o gênero Pinus, possui uma constituição anatômica mais simples que a das angiospermas, sendo formadas por traqueídeos e parênquimas, conforme indicado na Figura 2. Segundo Oliveira et al. (2007), os traqueídeos exercem maior função estrutural do que o parênquima.

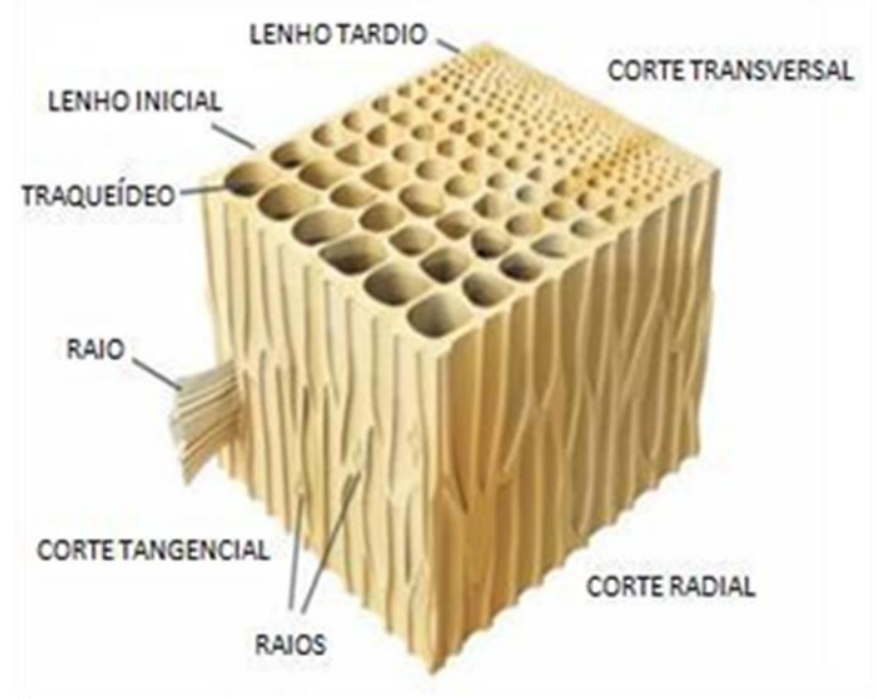

Figura 2: Estrutura anatômica de gimnospermas. Fonte: Gonzaga (2006).

No Brasil, os dois exemplos mais importantes de gimnospermas são: Pinho do Paraná (Araucaria angustifolia) e as espécies que compõem o gênero Pinus, também chamados de coníferas, softwood ou "madeiras moles". Segundo a Empresa Brasileira de Pesquisas Agropecuárias (EMBRAPA), o gênero Pinus engloba mais de 100 espécies com potencial a ser explorado.

Alfonso et al. (1988), enfatiza que os Pinus possuem tronco reto, praticamente cilíndrico, e sua copa tem formato de cone. De um modo geral, os Pinus não necessitam de solos férteis, desenvolvendo-se bem em solos ácidos e com pouca disponibilidade de matéria orgânica. As espécies deste gênero preferem os solos arenosos e profundos, característicos dos cerrados e dos campos.

Bortoletto Jr. (1993), comenta que, em princípio, a introdução de espécies exóticas de coníferas no Brasil foi para fins ornamentais, em seguida, com finalidades silviculturais, Esta introdução foi determinada por duas razões principais: suprir a escassez de matéria-prima causada pelo extrativismo predatório das reservas naturais de Pinho do Paraná (Araucaria angustifolia) e reduzir a dependência nacional da importação de celulose de fibra longa, papel, resina e seus derivados. A Figura 3 exemplifica um plantio de Pinus elliottii. 


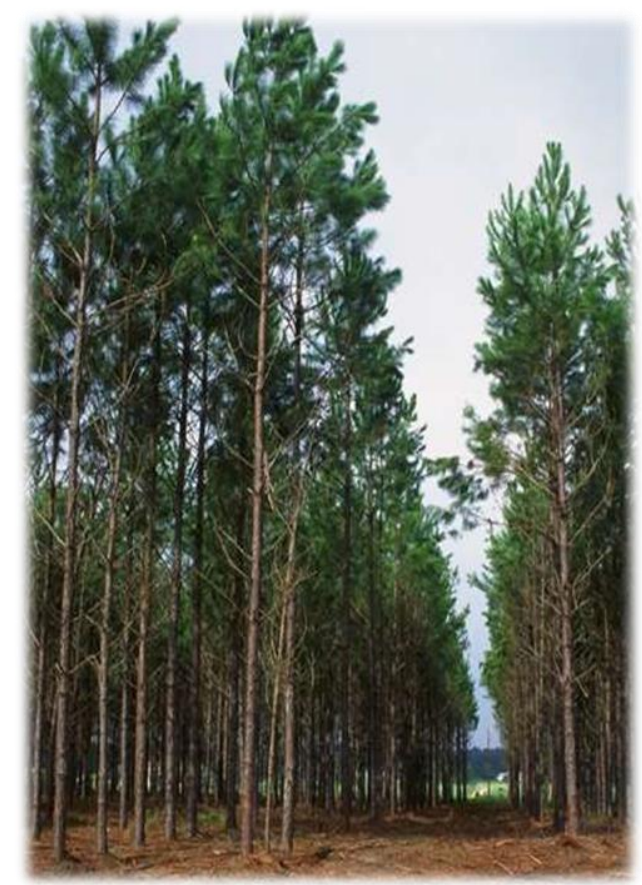

Figura 3: Cultivo de Pinus elliottii.

Fonte: EMBRAPA (2010)

Shimizu (2006) aponta que, em 1936, iniciou-se a produção de Pinus com finalidade silvicultural e em 1948 o Serviço Florestal do Estado de São Paulo introduziu algumas espécies norte americanas conhecidas por produzir madeira de cor clara, variando de branca a amarelada, que incluem o $P$. palustris, $P$. echinata, $P$. elliottii e o $P$. taeda, destacando-se as duas últimas pela facilidade no trato cultural, rápido crescimento e reprodução intensa.

O Pinus taeda é o mais plantado e utilizado industrialmente na região Sul do País (SHIMIZU, 2008). Para garantir fornecimento de matéria prima à indústria, preços competitivos, utilização e consolidação da madeira de Pinus em alguns segmentos industriais, tornam-se necessários não apenas incentivos ao aumento das áreas plantadas com o P. taeda, mas também, direcionamento de esforços no desenvolvimento de pesquisas relacionadas a introdução e qualificação da madeira de outras espécies. Entre essas, é possível citar as espécies de Pinus tropicais, as quais podem aumentar a produtividade, volume de madeira ofertado e diversificação de matéria prima.

A espécie tropical Pinus caribaea abrange três variedades naturais: $P$. caribaea, $P$. bahamensis e P. hondurensis (FACCIO, 2010). Entre as espécies e variedades de Pinus tropicais, o caribaea é a que apresenta a melhor forma de fuste, com ramos finos e curtos. Estas características contribuem para a formação de madeira de alta qualidade para serraria. Segundo Serpa e Vital (2005), dentre as empresas que utilizam Pinus em seus processos produtivos, $48 \%$ concentram-se na indústria de madeira serrada. 
Atualmente a área compreendida por plantações dos vários gêneros da espécie Pinus ocupam uma área de mais de 2 milhões de hectares, e concentram-se no Paraná (42,4\%) e em Santa Catarina (34,1\%). Além dos Eucalyptus, estão entre as outras espécies plantadas no País: Acácia, Teca, Seringueira e Paricá, segundo dados do SNIF - Sistema Nacional de Informações Florestais, portal de informações do governo federal, como é possível verificar por meio da Figura 4 (SNIF, 2016).

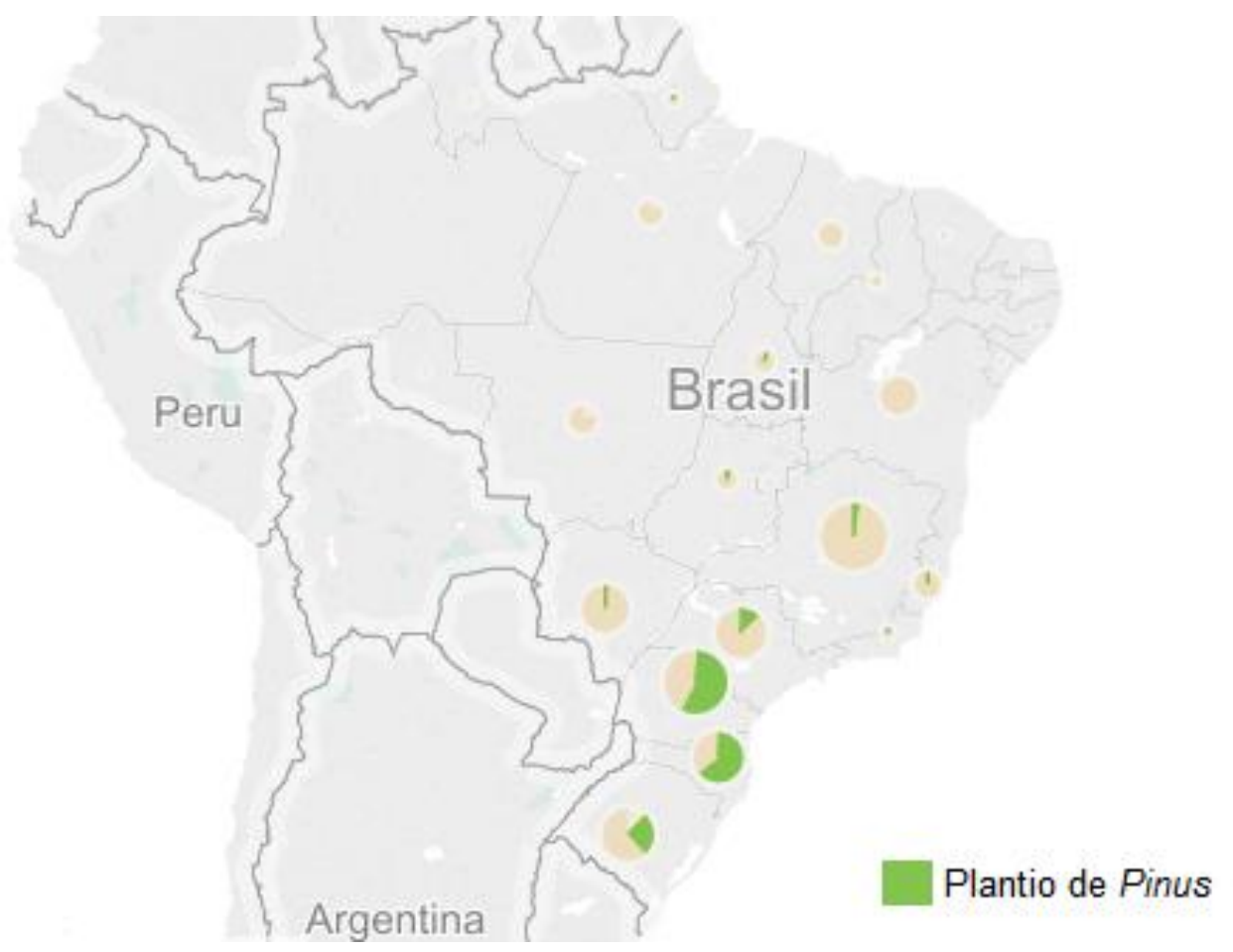

Figura 4: Área ocupada por plantações de Pinus.

Fonte: SNIF (2016).

As espécies deste gênero são produtoras de grandes quantidades de madeira, tem altos índices de aproveitamento, desde o tronco - matéria-prima para a produção de celulose de fibra longa, papel de qualidade superior, MDF, OSB, compensados, fabricação de sarrafos, lambris, ripas, vigas, postes, tábuas para embalagens, móveis e partículas - como também a casca, utilizada como substrato para plantas.

O gênero como um todo pode produzir resina, que destilada fornecerá o Breu, usado na produção de colas, vernizes, tintas e adesivos e a Terebintina, usada na indústria de solventes, fungicidas, germicidas e cânfora sintética. Segundo Auer (2005), a espécie com maior produtividade de resina é o Pinus elliottii. Após todo o processo de resinagem, a madeira ainda pode ser usada na serraria e, principalmente, usada na indústria de celulose. Porém deve-se tomar as devidas precauções, devido ao fato de a madeira poder ficar abrasiva, após este processo.

Em 2012 a produção de madeira serrada de Pinus no Brasil foi 9,2 milhões de $\mathrm{m}^{3}$, sendo 90\% destinados ao consumo doméstico. Estimativas projetam um crescimento anual de 2,7\% no consumo interno da madeira serrada de Pinus (ABRAF, 2013). 


\subsection{Madeira na construção civil}

Apesar da grande incidência de estruturas de madeira, até as primeiras décadas do século XIX pouco se conhecia a respeito das características físicas, de resistência e de elasticidade da madeira. Além disso, havia apenas aplicações baseadas em obras anteriores. Portanto, não eram comuns projetos estruturais mais elaborados. A partir do início do século XX, deu-se a evolução dos processos de cálculo por parte de alguns estudiosos, tornando o emprego da madeira mais diversificado e racional (CESAR, 1991).

Nacionalmente, o emprego da madeira na construção de estruturas nem sempre ocorre em condições satisfatórias no tocante à tecnologia agregada ao material, apesar de sua versatilidade e de sua disponibilidade. (ZANGIÁCOMO, 2003). No âmbito global, o desenvolvimento tecnológico da madeira como material estrutural cresce substancialmente, aumentando a industrialização das construções em madeira.

Apesar de ainda ser pouco explorada no Brasil, um dos maiores consumidores de madeira é a construção civil. A madeira serrada é empregada na construção civil, de forma temporária, na instalação do canteiro de obras, como tapumes, nos andaimes, nos escoramentos e nas fôrmas (Figura 5).
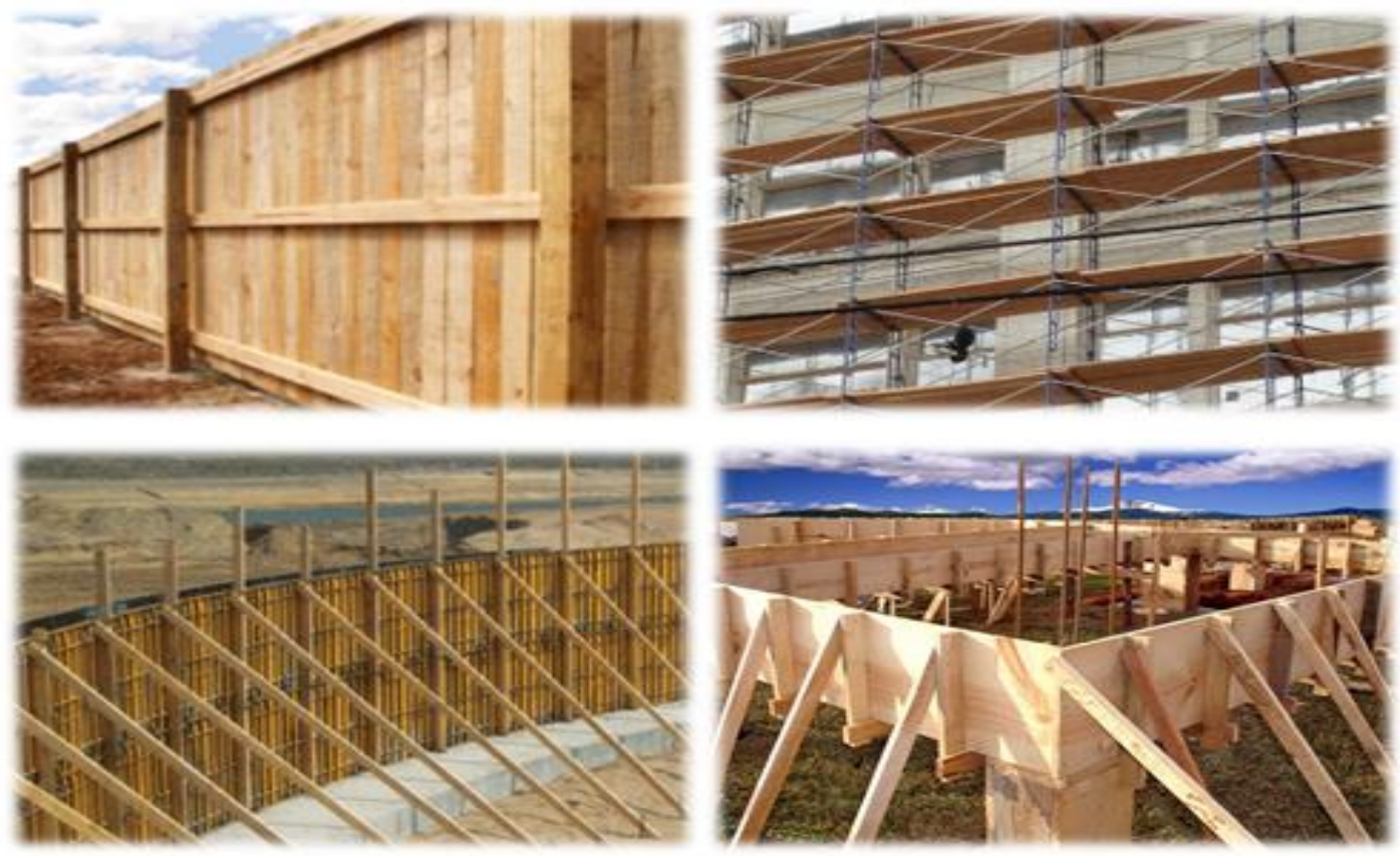

Figura 5: Usos temporários da madeira na construção civil. 
O uso estrutural da madeira deste gênero tem sido crescente, sobretudo pela indisponibilidade de madeiras nativas, tradicionalmente usadas nesse segmento. Razões mercadológicas tornam a madeira de Pinus uma boa opção, sobretudo quando do uso de estruturas pré-fabricadas.

A produção desta madeira tem ciclos mais curtos, o que torna comum o decréscimo na oferta de árvores adultas com grandes diâmetros. Além do aspecto da juvenilidade (BALLARIN \& LARA PALMA, 2003), nota-se que a madeira disponível para uso industrial e comercial apresenta uma incidência muito grande de nós e outros defeitos, que podem comprometer significativamente seu desempenho físico-mecânico e sua qualidade.

A madeira como material da construção civil normalmente se encontra em diferentes formas, tais como: madeira em tora; madeira serrada; madeira laminada colada; madeira compensada e madeiras reconstituídas. Atualmente, a madeira continua sendo muito empregada como estruturas treliçadas para coberturas destinadas a residências, barracões industriais e comerciais, instalações sócio-esportivas, em edificações rurais e pontes. Alguns exemplos de aplicações da madeira de forma definitiva são apresentados na Figura 6. Há também uma forte tendência em utilizá-la em sistemas construtivos.

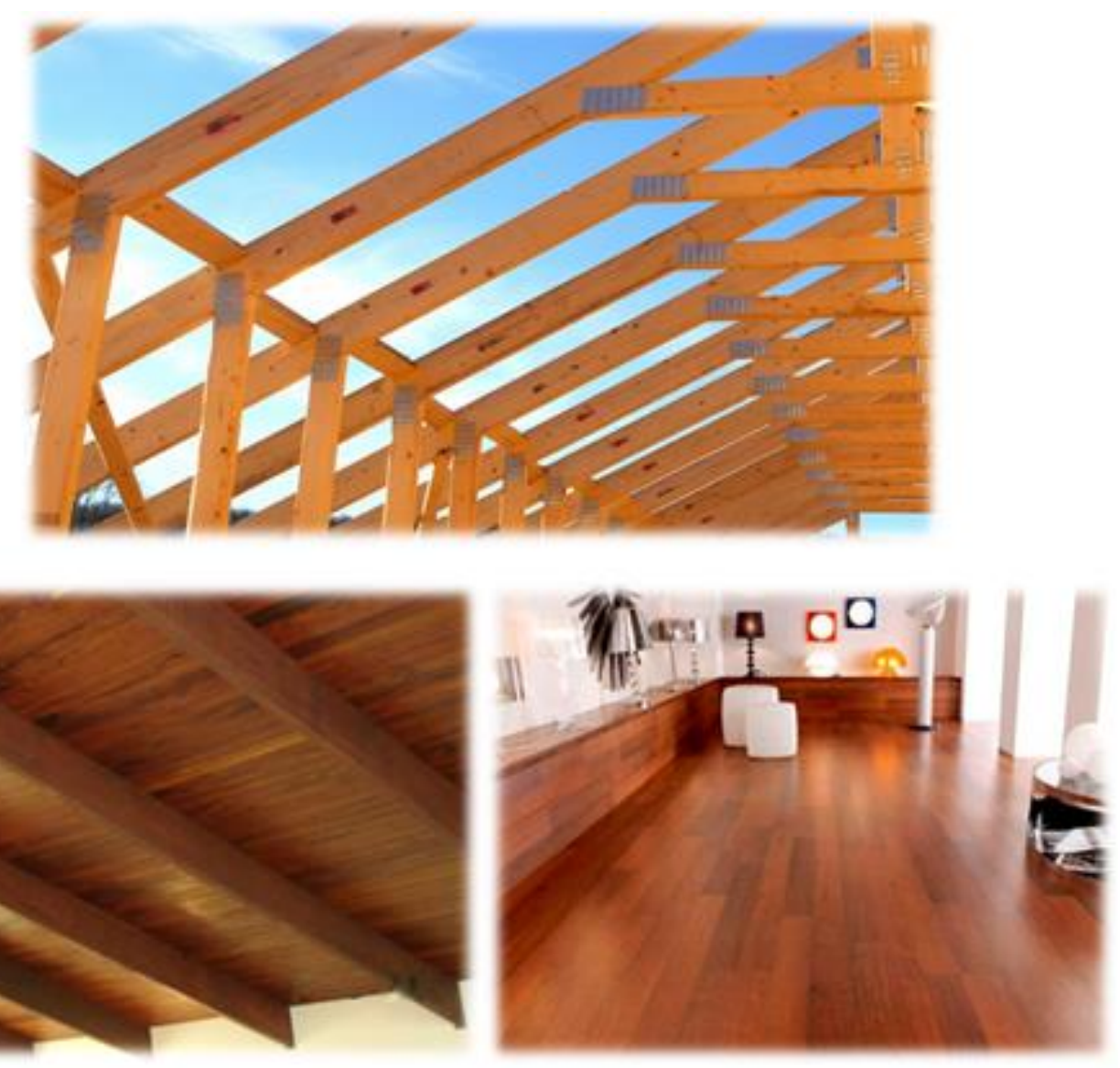

Figura 6: Usos definitivos da madeira na construção civil. 
O sistema wood-frame, acaba de ganhar normalização técnica no Brasil e está sendo apresentado como uma proposta alternativa de construção de edificações residenciais no País. A construção em wood-frame é mais tradicional em países da Europa e da América do Norte, onde o uso deste material é mais culturalmente aceito. O sistema wood-frame (Figura 7) é utilizado por 95\% das residências nos Estados Unidos (MOLINA; CALIL JUNIOR, 2010).

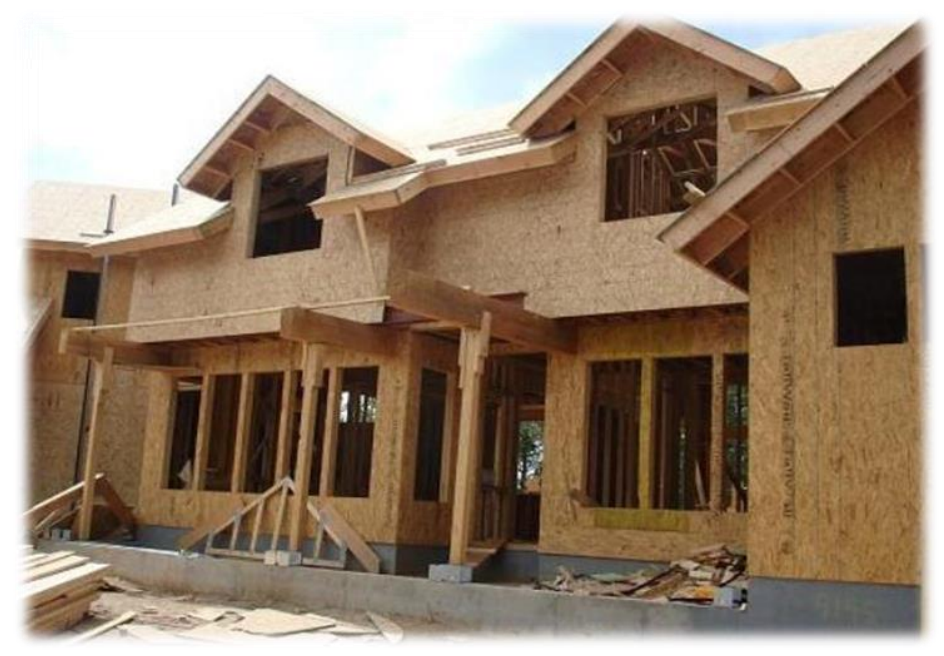

Figura 7: Sistema construtivo wood-frame.

Para Nahuz (2004), a madeira que era usada na construção habitacional nacional, concentrava-se entre 10 ou 12 espécies tradicionais (Cambará, Cupiúba, Maçaranduba, Cumaru, Pariri, Garapa, Itaúba, Tatajuba, Cedrinho, Ipê e Jatobá.). A escassez crescente destas madeiras e o seu alto preço provocou sua substituição por outras madeiras, mais abundantes e disponíveis a preços competitivos.

A demanda de madeiras como material de construção aumenta com a expansão do setor, não só nos usos tradicionais (estruturas, pisos e esquadrias), mas também como material principal. Esta expansão tem requerido matérias-primas de características uniformes, de amplo suprimento e baixo custo. Características estas encontradas principalmente em madeiras de florestas plantadas, homogêneas e de rápido crescimento (ICIMOTO, 2012).

Uma pequena desaceleração da construção civil nacional levou a uma queda de 6,1\% no consumo de madeira serrada, que passou de 8,51 milhões de metros cúbicos em 2013 para 7,99 milhões de metros cúbicos em 2014. No entanto, as exportações de madeira serrada de árvores plantadas alcançaram 1,24 milhão de metros cúbicos em 2014, um crescimento de 43,6\% em relação a 2013 (Figura 8). 


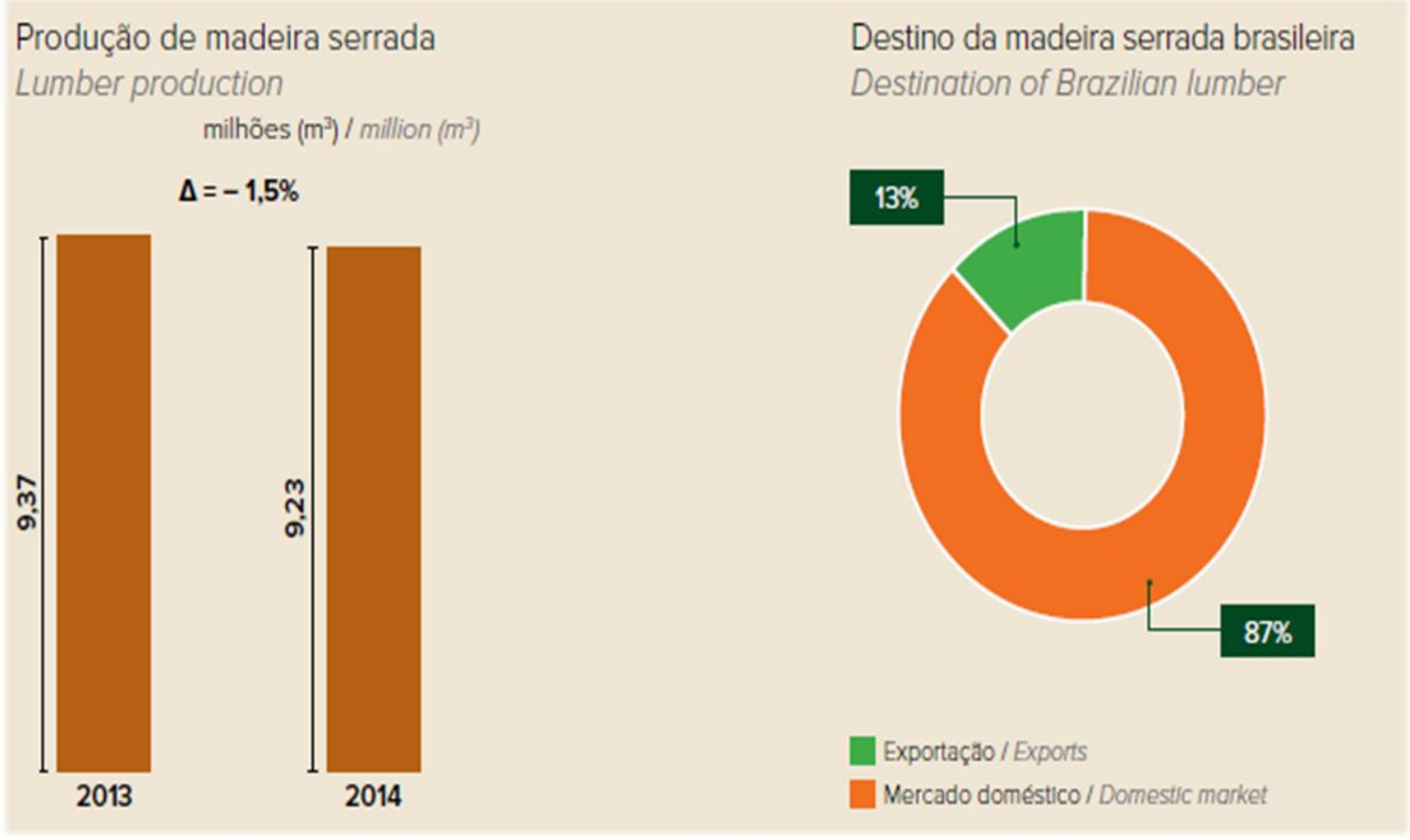

Figura 8: Indicadores do segmento madeira serrada. Fonte: IBÁ (2015).

Dentre a gama de materiais utilizados na construção civil, a madeira é único material de construção renovável, que demanda baixo consumo energético para produção, e sequestra carbono da atmosfera durante o crescimento da árvore (MOLINA; CALIL JUNIOR, 2010).

A sustentabilidade associada à madeira reintegra-a como um forte aliado das políticas ambientais que buscam a diminuição das emissões de dióxido de carbono, “[...] sendo que a indústria da construção é responsável pela emissão de um terço do total das emissões de dióxido de carbono para a atmosfera[...]" (SILVA; BRANCO; LOURENÇO, 2012).

A construção civil encontra, na madeira, um conjunto de características técnicas, econômicas e estéticas dificilmente disponíveis em outro material, porém, seu uso se restringe à utilização de poucas espécies com aceitação pelos usuários e construtores (NAHUZ, 2007).

Para o melhor aproveitamento é necessário que se conheça as propriedades físicas e mecânicas das espécies, possibilitando assim, a melhor aceitação no mercado interno e melhor exploração das propriedades positivas disponíveis. É fundamental que sejam aplicados rigorosos controles de secagem e classificação visual, objetivando a obtenção de melhor qualidade do produto final. 


\subsection{Classificação Visual}

Quando se trata da madeira, é pouco provável a obtenção da matéria-prima isenta de defeitos, que por fim possa ser aproveitada em sua totalidade. Por ser um material biológico, guarda consigo uma carga genética que determina suas características físicas e mecânicas e, como muitos seres vivos, possui particularidades que são acentuadas ou abrandadas conforme as condições ambientais.

A classificação visual está apoiada na premissa de que as propriedades mecânicas de uma peça estrutural são diferentes das propriedades mecânicas de corpos de prova isentos de defeitos em função da presença de características de crescimento. Tais características podem ser notadas e avaliadas antes de ser feita a classificação mecânica. Com o auxílio de regras de classificação, estas características de crescimento são usadas para selecionar a madeira em classes de qualidade (CARREIRA, 2003).

A utilização da madeira de reflorestamento de Pinus na indústria madeireira brasileira é extensiva. Nota-se que a madeira disponível para uso industrial e comercial apresenta uma incidência muito grande de defeitos, que podem comprometer significativamente seu desempenho físico-mecânico e sua qualidade.

Um dos defeitos constantes em muitas espécies de madeira, que é responsável por grande parte dos desvios de fibra e também por alterar significativamente as propriedades do material é a presença de nós. A Figura 9 mostra uma peça estrutural com a presença desse defeito após ter sido ensaiada

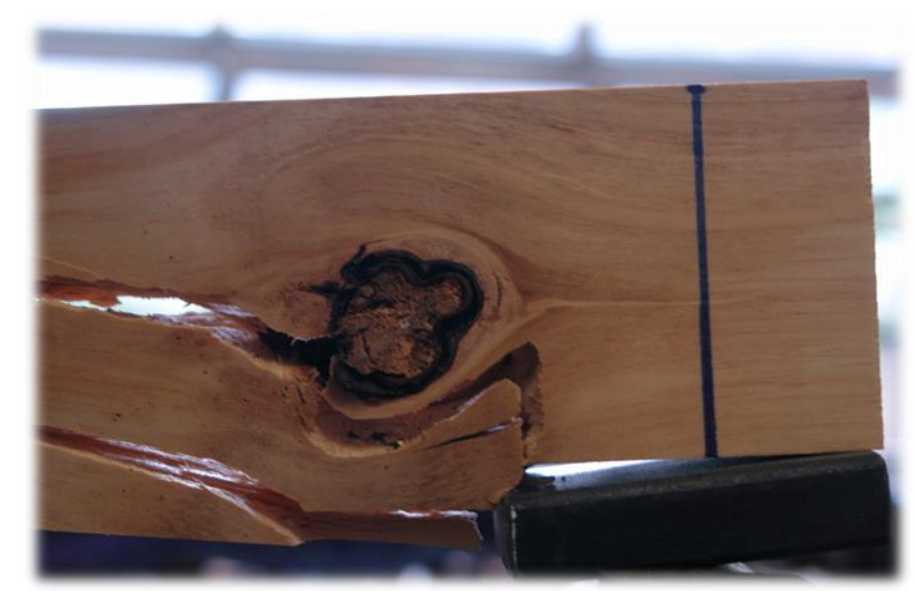

Figura 9: Detalhe da presença de nós em peças estruturais de madeira. Fonte: o Autor. 
A existência de nós dificulta o processo de desdobro, aplainamento, colagem e acabamento, propiciando assim o surgimento de problemas patológicos, como por exemplo, fissuras em elementos estruturais de madeira.

A norma brasileira NBR 7190 - Projeto de estruturas de madeira (ABNT, 1997), atualmente vigente, não contempla procedimentos para a classificação visual da madeira serrada para uso estrutural.

Este tipo de classificação é praticada para levar-se em consideração os impactos causados nas propriedades de resistência e rigidez por intermédio de nós, distorção das fibras, arqueamento, torcimento, presença de medula, esmoados, fungos, insetos e demais defeitos. É o primeiro e o mais tradicional método não destrutivo de classificação, que consiste em uma análise das peças por um profissional de larga experiência. A classificação é feita com base no número e dimensão dos defeitos (GONÇALVES, 2000).

Carreira (2003) propõe quatro "níveis" ou “classes” de qualidade (SS; S1, S2 e S3), estabelecidos com base nos defeitos visualmente detectados. A tendência mais recente no tocante a classificação visual, expressa em relatório do Forest Products Laboratory (WHITE, 2014) reduz o número de classes visuais para três, facilitando o processo classificatório, desempenhado muitas vezes por classificadores humanos.

Na América do Norte, o Pinus elliottii recebe o nome comercial de "Slash Pine" e o Pinus taeda o nome de "Loblolly Pine". Ambos fazem parte do grupo Southern Pine e são classificados segundo as regras do Southern Pine Inspection Bureau (SPIB, 1994). As mesmas regras foram aplicadas neste trabalho para constatar a presença de defeitos em corpos de prova estruturais.

\subsection{Ensaios de Caracterização}

Um fator importante a ser considerado por um projetista é como o material selecionado se comportará sob um determinado carregamento. $O$ interesse na determinação das propriedades da madeira é justificado pelo fato de que na maioria das situações de sua utilização, as tensões devem ser conhecidas, permitindo assim dimensionamento correto dos vários elementos que compõem o conjunto estrutural como um todo. 
A primeira iniciativa nacional de caracterização foi feita na Escola Politécnica de São Paulo, em 1904, na qual realizou estudos sobre a resistência à compressão, flexão e determinação da densidade de diversas espécies nativas (RODRIGUES, 2002).

Por volta de 1930, o Instituto de Pesquisas Tecnológicas (IPT) publicou alguns Métodos para Ensaios de Madeiras, nos quais fundamentou o desenvolvimento da pesquisa objetivando a caracterização de espécies de madeiras produzidas no País. Esses métodos foram divididos em: ensaios físicos (umidade, densidade e retratibilidade) e ensaios mecânicos (compressão paralela, flexão estática, choque, tração, fendilhamento, dureza e cisalhamento).

Em 1940, a então recém instalada Associação Brasileira de Normas Técnicas adotou os métodos descritos pelo IPT, transformando-os no MB-26/40: (NBR 6230) - Método Brasileiro para Ensaios Físicos e Mecânicos de Madeiras.

O Laboratório de Madeiras e Estruturas de Madeiras (LaMEM), do Departamento de Engenharia de Estruturas (SET), da Escola de Engenharia de São Carlos, em 1987, contribuiu para a caracterização de madeiras com propostas de métodos de ensaio para a determinação das características físicas, de resistência e de elasticidade da madeira.

Estes conhecimentos adquiridos, somados as experiências da Escola Politécnica levaram a elaboração pela ABNT da NBR 7190:1997 - Projeto de estruturas de madeira, que trata da determinação das propriedades das madeiras para projetos estruturais.

Atualmente a caracterização físico-mecânica ainda é feita seguindo os ensaios propostos pela ABNT NBR 7190:1997, que se encontra em processo de revisão. De uma maneira geral a norma brasileira de madeiras recomenda três tipos de caracterização para madeira: completa, mínima e simplificada.

A caracterização completa estabelece as propriedades físicas e mecânicas da madeira que devem ser determinadas. As propriedades físicas a serem determinadas são: a massa especifica aparente, a retratibilidade e a umidade. As propriedades mecânicas são a resistência a compressão paralela às fibras, a tração paralela às fibras, a compressão normal às fibras, a tração normal às fibras, ao cisalhamento paralelo às fibras, ao embutimento paralelo e normal às fibras, fendilhamento, dureza paralela e perpendicular, além da tenacidade (flexão-impacto).

O segundo tipo de caracterização é a mínima, onde são determinados os valores de resistência a tração e a compressão na direção das fibras, a resistência ao cisalhamento, além dos valores de densidade básica e aparente. 
O terceiro tipo de caracterização recomendada pela norma brasileira de madeiras é a caracterização simplificada, que é utilizada para espécies de madeiras usuais. Neste caso, a norma recomenda algumas equações para a obtenção dos valores de resistência em função da resistência da madeira obtida para a compressão na direção das fibras.

As características físico-mecânicas de dezesseis espécies do gênero Eucalyptus foram estudadas por Nogueira (1991). Os resultados são apresentados seguindo os padrões da norma brasileira de madeiras: densidade aparente entre 0,63 e 1,09 g/ $/ \mathrm{cm}^{3}$; contrações: tangencial entre 7,06 e 12,53\% e radial entre 4,05 e 8,91\%. Quanto as propriedades mecânicas: resistência à compressão paralela entre 40 e $81 \mathrm{MPa}$, o módulo de resistência na flexão entre 72 e 225 MPa e módulo de elasticidade na flexão entre 12086 e $20495 \mathrm{MPa}$.

No que diz respeito às características da madeira de coníferas, Bortoletto Jr. (2008), em seu estudo analisou as propriedades dos Pinus spp. encontrados no Estado de São Paulo. Os valores foram: densidade aparente entre 0,54 e $0,64 \mathrm{~g} / \mathrm{cm}^{3}$, contrações: tangencial entre 5,66 e 7,40\% e radial entre 3,50 e 6,34\%, resistência a compressão paralela entre 33 e $44 \mathrm{MPa}$, módulo de resistência na flexão entre 60 e 104 MPa e módulo de elasticidade na flexão entre 6558 e 14477 MPa.

O método de ensaio brasileiro, foi utilizado por Sales (1996), no estudo das propriedades físico-mecânicas de espécies nativas. Para as espécies utilizadas em estruturas, como por exemplo, Cedro doce (Cedrella spp) Cupiúba (Goupia glabra), Ipê (Tabebuia serratifolia), Maçaranduba (Manilkara spp) e Jatobá (Hymenaea spp), os valores apresentados são respectivamente: $0,50,0,84,1,07,1,14$ e $1,07 \mathrm{~g} / \mathrm{cm}^{3}$ para as densidades aparentes; 31,5, 54,4, 76,0, 82,9 e 93,3 MPa para resistência a compressão paralela às fibras; 5,6, 10,4, 13,1, 14,9 e 15,7 MPa para resistência ao cisalhamento.

O documento normativo brasileiro, apresenta classes de resistência para coníferas e folhosas (dicotiledôneas), orientando a escolha do material para projetos estruturais. Abaixo seguem duas tabelas (Tabela 2 e Tabela 3) encontradas no projeto de norma PN02:126.10-001-1, que revisa a ABNT NBR 7190:1997. Os valores tabelados, neste caso, se encontram nos padrões normais de referência, com teor de umidade igual a 12\%. Com a utilização do sistema de classes de resistência torna-se possível a disseminação do uso de madeiras de reflorestamento na construção civil. 
Tabela 2: Classes de resistência das coníferas.

\begin{tabular}{lcccc}
\hline \hline \multicolumn{5}{c}{ Coníferas } \\
\hline Classes & $\begin{array}{c}\mathbf{f}_{\mathbf{c 0 k}} \\
\mathbf{M P a}\end{array}$ & $\begin{array}{c}\mathbf{f}_{\mathbf{v}} \\
\mathbf{M P a}\end{array}$ & $\begin{array}{c}\mathbf{E}_{\mathbf{c 0}, \mathbf{m}} \\
\mathbf{M P a}\end{array}$ & $\begin{array}{c}\boldsymbol{\rho}_{\mathbf{a p}} \\
\mathbf{k g} / \mathbf{m}^{3}\end{array}$ \\
\hline $\mathbf{C 2 0}$ & 20 & 4 & 3500 & 500 \\
\hline $\mathbf{C 2 5}$ & 25 & 5 & 8500 & 550 \\
\hline $\mathbf{C 3 0}$ & 30 & 6 & 14500 & 600 \\
\hline \hline
\end{tabular}

Fonte: ABNT PN02:126.10-001-1 (Adaptada).

Tabela 3: Classes de resistência das dicotiledôneas.

\begin{tabular}{ccccc}
\hline \multicolumn{5}{c}{ Dicotiledôneas } \\
\hline Classes & $\begin{array}{c}\mathbf{f}_{\mathbf{c 0 k}} \\
\mathbf{M P a}\end{array}$ & $\begin{array}{c}\mathbf{f}_{\mathbf{v k}} \\
\mathbf{M P a}\end{array}$ & $\begin{array}{c}\mathbf{E}_{\mathbf{c 0}, \mathbf{m}} \\
\mathbf{M P a}\end{array}$ & $\begin{array}{c}\boldsymbol{\rho}_{\mathbf{a p}} \\
\mathbf{k g} / \mathbf{m}^{3}\end{array}$ \\
\hline D20 & 20 & 4 & 9500 & 650 \\
\hline D30 & 30 & 5 & 14500 & 800 \\
\hline D40 & 40 & 6 & 19500 & 950 \\
\hline D50 & 50 & 7 & 22000 & 970 \\
\hline D60 & 60 & 8 & 24500 & 1000 \\
\hline \hline
\end{tabular}

Fonte: ABNT PN02:126.10-001-1 (Adaptada).

No Brasil, a caracterização mecânica de madeiras deve respeitar os métodos de ensaio especificados no Anexo B da ABNT NBR 7190:1997 - "Determinação das Propriedades das Madeiras para Projetos Estruturais”. Este documento até o momento não contempla ensaios em peças de madeira de dimensões reais. A resistência e a rigidez são determinadas através de ensaios realizados em corpos de prova de pequenas dimensões e isentos de defeitos. Os valores das propriedades neste caso, após calculados, devem ser corrigidos para a condição-padrão de umidade $(\mathrm{U}=12 \%)$. 


\subsubsection{Planos e direções da madeira}

Quando são estudados ensaios de caracterização, é importante ressaltar as diferenças anatômicas e também macromoleculares da madeira. A estrutura anatômica além de influenciar na aparência da madeira, afeta o comportamento físico-mecânico da mesma, dependendo do plano considerado.

A estrutura macroscópica representa o que se pode enxergar com aumento de até dez vezes. Nesta óptica, são designados três planos e três direções de orientações na madeira (COUTINHO, 1999). A madeira é um material ortotrópico e, portanto, apresenta diferentes propriedades de resistência e rigidez conforme a direção das solicitações externas em relação à direção principal das suas fibras.

A Figura 10, evidencia os planos e direções citados, que são determinados em relação à disposição das fibras que constituem o lenho (CALIL et al., 2003; GALVÃO \& JANKOWSKY, 1985; BODIG \& JAYNE, 1982).

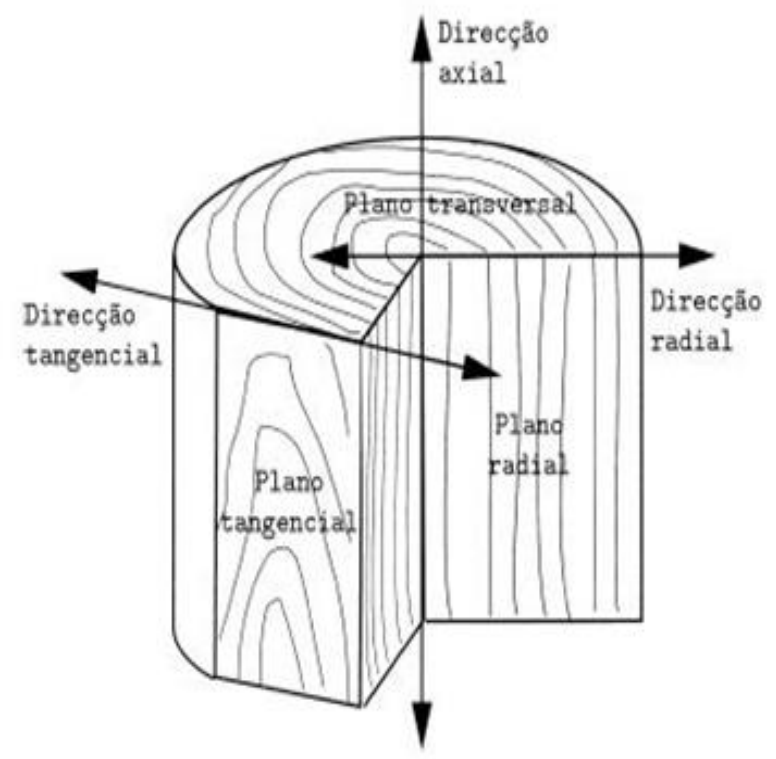

Figura 10: Direções e planos fundamentais da madeira.

Fonte: Chapelet (1991, apud MACHADO, 2006).

Em geral, a madeira apresenta resistências superiores quando submetida a esforços na direção paralela às fibras, pois as forças agem paralelamente ao comprimento de suas células (direção de maior resistência) que, agindo em conjunto, conferem uma grande resistência ao material (BODIG \& JAYNE, 1982). 
Almeida (1990) explica que a fisiologia da árvore define um sistema vascular orientado na direção longitudinal e radial ao tronco, formada por elementos "tubulares" denominados de fibras. Os elementos transversais esquematizados na Figura 11 representam as células de raio, que exercem resistência perpendicular aos esforços ao sentido paralelo às fibras da madeira.
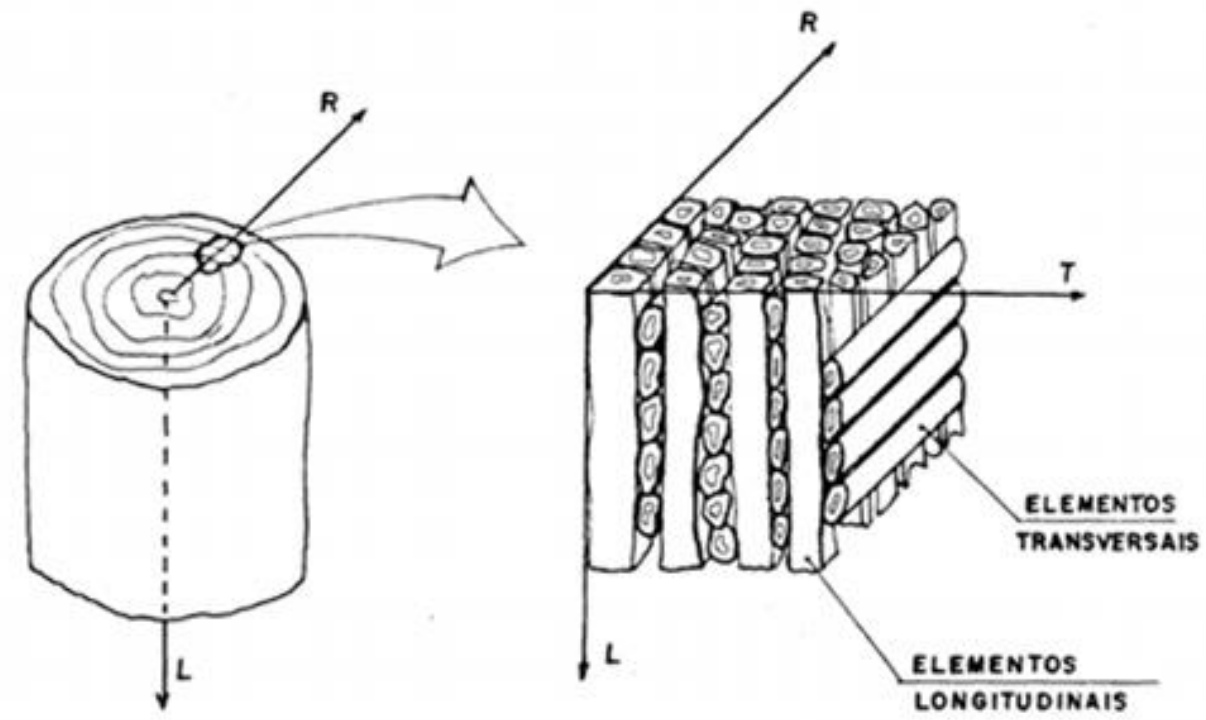

Figura 11: Arranjo esquemático da estrutura interna da madeira.

Fonte: ALMEIDA, P. A. O. (1990)

\subsubsection{Resistencia ao Cisalhamento}

Na madeira existem disponíveis vários procedimentos de ensaio para determinar o limite da tensão de cisalhamento, ou a chamada resistência ao cisalhamento. Segundo Oliveira (1988), resistência ao cisalhamento é a capacidade da madeira em suportar à ação de cargas que tendem a fazer com que uma parte do material deslize sobre outra adjacente.

O cisalhamento na madeira pode ocorrer sob três formas: a primeira acontece quando a ação é perpendicular às fibras (Figura 12), porém este tipo de solicitação não é crítico pois antes de romper a peça apresentará problemas de esmagamento por compressão normal. 


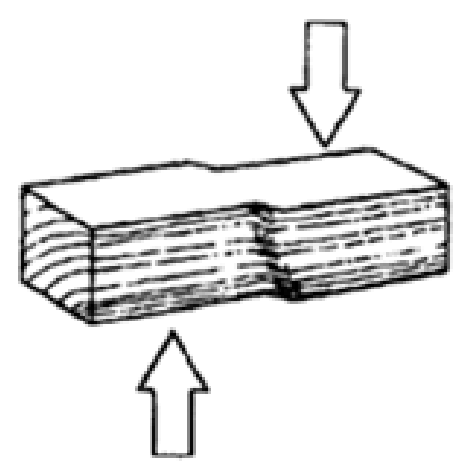

Figura 12: Cisalhamento perpendicular às fibras. Fonte: RITTER (1990).

As outras duas formas de cisalhamento ocorrem com a força aplicada no sentido longitudinal às fibras, e perpendicular às linhas dos anéis de crescimento, chamado de "rolling shear”. Na Figura 13 é evidenciado o caso mais crítico, observa-se a tendência que existe das células da madeira se separarem e escorregarem longitudinalmente, este é o cisalhamento paralelo às fibras. Na Figura 14, é ilustrada a tendência de ocorrer uma "rolagem" das células da madeira umas sobre as outras de forma transversal em relação ao eixo longitudinal.

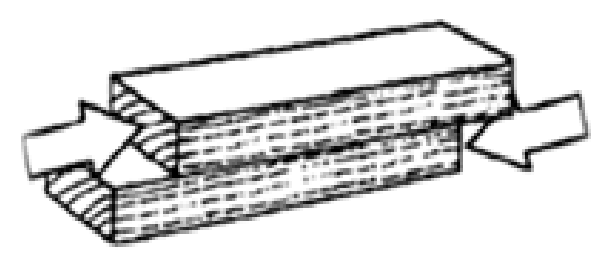

Figura 13: Cisalhamento paralelo às fibras. Fonte: RITTER (1990).

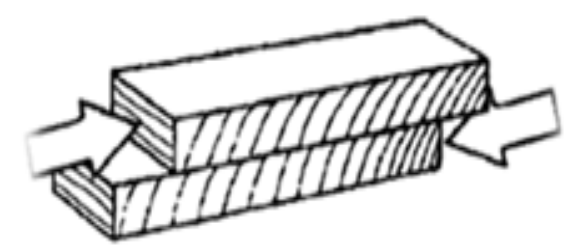

Figura 14: Cisalhamento perpendicular aos anéis de crescimento - rolling shear. Fonte: RITTER (1990).

A resistência ao cisalhamento da madeira é diretamente proporcional à sua densidade, mas depende principalmente do sentido em que o esforço é aplicado em relação aos anéis de crescimento (usualmente a ruptura se dá no plano tangencial ou radial). No plano tangencial há uma grande influência da diferença entre os lenhos inicial e tardio, enquanto que no plano radial há grande influência dos raios da madeira. 
O procedimento utilizado atualmente pelo documento normativo nacional, consiste em apoiar uma porção da base do corpo de prova e, com uma ferramenta aplicar uma carga compressiva, paralela às fibras da madeira, até ser obtida a carga-limite para cisalhamento simples. A área a ser considerada para o cálculo da resistência deve ser a área cisalhada. Feito isso calcula-se a resistência ao cisalhamento paralelo às fibras .

Teoricamente, o cisalhamento da madeira consiste na separação das suas fibras causada por esforços contrários, paralelos às mesmas, por deslizamento. Contudo, pesquisadores observaram que durante o ensaio proposto pela ABNT NBR 7190:1997 existem distorções nos resultados devido a excentricidades de carga. Estas distorções têm sido estudadas e analisadas gerando propostas de novas metodologias a fim de diminuir possíveis desvios (HARA et al., 2014).

A resistência ao cisalhamento paralelo às fibras merece atenção especial neste estudo, devido à importância de seus resultados para o dimensionamento de elementos estruturais em que o uso de valores inexatos pode causar danos materiais e outras consequências (EVANS, J. L.W.; SENFT, J. F.; GREEN, 2000).

Retomando aos valores apresentados nas tabelas de classe de resistência da ABNT NBR 7190:1997 (Tabela 2 e Tabela 3) pode-se observar valores característicos de resistência ao cisalhamento variando entre 4 e $6 \mathrm{MPa}$ para as coníferas e entre 4 e $8 \mathrm{MPa}$ para as dicotiledôneas.

\subsection{Normas vigentes e métodos de ensaio}

Nos itens seguintes são apresentados detalhes dos métodos de ensaio normalizados para a determinação da resistência da madeira ao cisalhamento na direção paralela às fibras. Serão apresentados o método brasileiro, que utiliza corpos de prova reduzidos e isentos de defeitos, e os métodos americano e europeu, para peças com dimensões estruturais, buscando evidenciar a variabilidade presente nas madeiras de reflorestamento, a influência dos defeitos nas propriedades e as diferenças entre os resultados obtidos com espécies listadas na literatura. 


\subsubsection{ABNT NBR 7190:1997}

Conforme o item B.12 do Anexo B da norma ABNT NBR 7190:1997 - Projeto de Estruturas de Madeira, para a determinação da resistência ao cisalhamento paralelo às fibras da madeira de um lote considerado homogêneo, a resistência ao cisalhamento $\left(f_{v 0}\right)$ é dada pela máxima tensão de cisalhamento que pode atuar na seção crítica de um corpo de prova prismático, sendo dada por (Equação 1):

$$
f_{v 0}=\frac{F_{v 0, \max }}{A_{v 0}}
$$

Onde:

$F_{v 0, \text { max }}:$ máxima força aplicada ao corpo de prova durante o ensaio, em $\mathrm{N}$;

$A_{v 0}$ : área da seção cisalhante, em $\mathrm{mm}^{2}$;

$f_{v 0}$ : resistência ao cisalhamento paralelo às fibras, em MPa.

O corpo de prova para o ensaio de cisalhamento paralelo às fibras seguindo a norma brasileira de madeiras deve ter as dimensões indicadas na Figura 15.

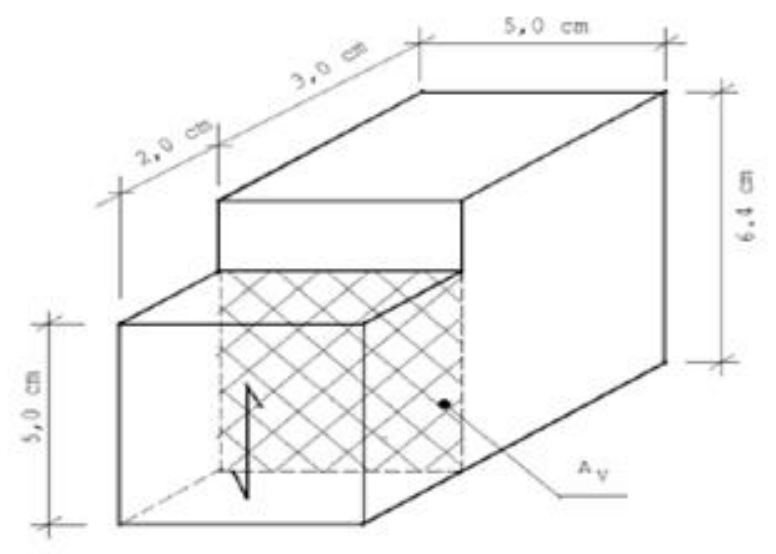

Figura 15: Corpo de prova para o ensaio de cisalhamento. Fonte: ABNT NBR 7190:1997.

Para a determinação da resistência ao cisalhamento paralelo às fibras, as medidas dos lados dos corpos de prova devem ser feitas com exatidão de $0,1 \mathrm{~mm}$. Para o ajuste do corpo de prova na máquina de ensaio deve-se utilizar uma rótula entre o atuador e o corpo de prova. $\mathrm{O}$ carregamento deve ser monotônico crescente, correspondente a uma taxa de 2,5 MPa/min. 
O ensaio consiste na aplicação e na mensuração do esforço no sentido das fibras, para provocar o deslizamento entre as mesmas. A seção de trabalho pode variar, de modo que o cisalhamento ocorra na face tangencial ou na face radial da madeira a qual normalmente mede $5 \times 5 \mathrm{~cm}$. O arranjo de ensaio para a determinação da resistência ao cisalhamento paralelo está indicado na Figura 16.

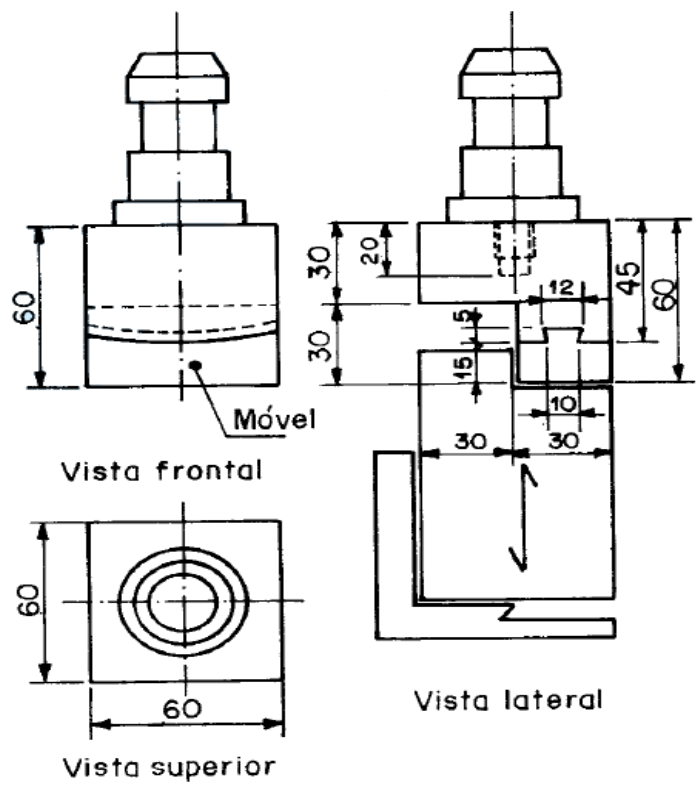

Figura 16: Arranjo de ensaio para a determinação da resistência ao cisalhamento. Fonte: ABNT NBR 7190:1997.

As seções de trabalho podem variar em função da orientação de corte da madeira: tangencialmente aos anéis de crescimento (a) e perpendicularmente aos anéis de crescimento (b), como ilustrado na Figura 17. Os corpos de prova com orientação de corte perpendicular e tangencial aos anéis de crescimento estão demonstrados na Figura 18.
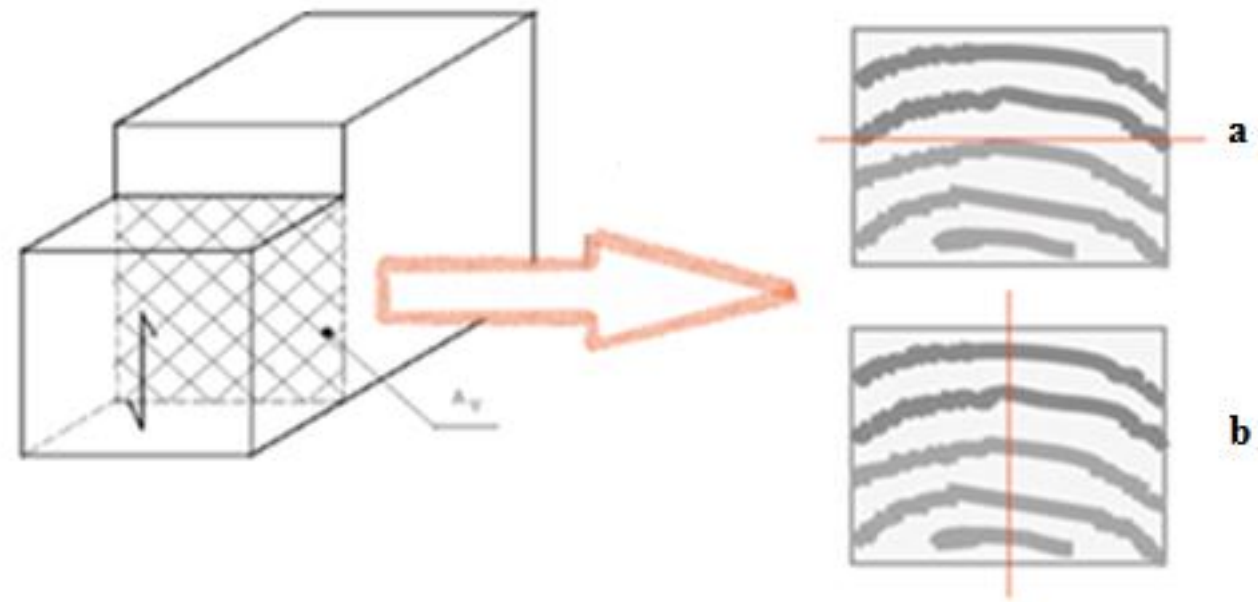

Figura 17: Seções de trabalho em função da orientação de corte da madeira. 


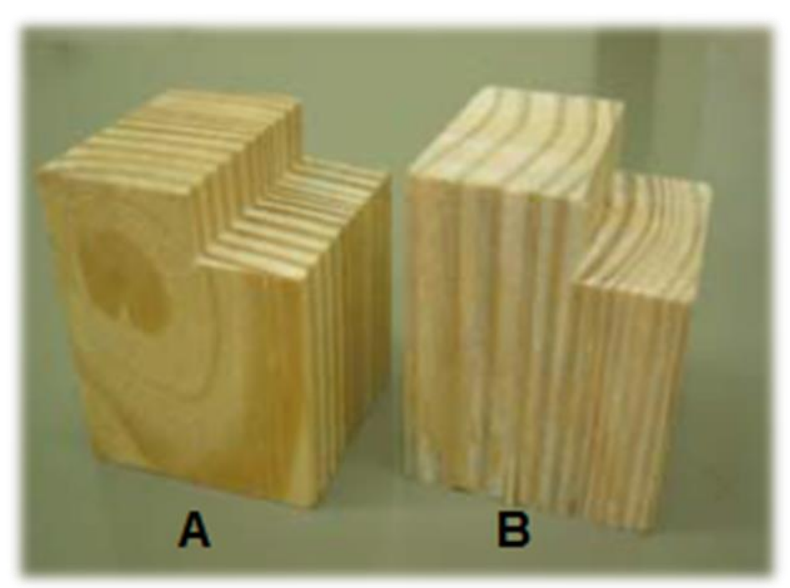

Figura 18: A - Corte perpendicular; e B - Corte tangencial aos anéis de crescimento.

$\mathrm{O}$ valor característico da resistência ao cisalhamento paralelo às fibras $\left(f_{v k}\right)$ deve ser determinado pelo estimador apresentado na Equação 2.

$$
f_{v k}=\left(2 \frac{f_{v 1}+f_{v 2}+\cdots+f_{\frac{n}{2}-1}}{\frac{n}{2}-1}-f_{\frac{n}{2}}\right) 1,1
$$

Onde os resultados devem ser colocados em ordem crescente $f_{v 1} \leq f_{v 2} \leq \ldots \leq f_{n}$, desprezando-se o valor mais alto se o número de corpos de prova for ímpar, não se tomando para $f_{v k}$ valor inferior a $f_{v 1}$, nem a 0,7 do valor médio $\left(f_{m}\right)$.

\subsubsection{ASTM ISO 13910:2005}

O documento norte americano intitulado ASTM ISO 13910: "Structural timber Characteristic values of strength-graded timber - Sampling, full-size testing and evaluation" vigente desde 2005, fornece os requisitos para amostragem, ensaio e avaliação dos valores característicos de propriedades estruturais. Durante a execução desta pesquisa, este documento passou por um processo de revisão e, portanto, conduziram-se ensaios segundo o modelo atual apresentado.

Os ensaios, neste caso, são conduzidos em peças de tamanho real para a determinação dos valores de resistência. Define-se elemento estrutural como sendo uma madeira de seção retangular e comprimento produzido para fins de construção. 
Todos os corpos de prova devem ser cortados a partir de peças que foram selecionadas para representar uma população de referência. A representação da população de referência pode ser obtida através da seleção de peças aleatoriamente. No entanto, a melhor representação pode ser obtida se todos os parâmetros populacionais, tais como a proporção de peças produzidas por cada talhão, forem replicados na amostra selecionada para o ensaio.

A amostra mínima de 40 peças deve ser utilizada para cada série, ou tamanho, ou propriedade a ser avaliada. Um tamanho de amostra maior do que 40 é recomendado de modo a proporcionar valores característicos mais confiáveis.

Os corpos de prova devem ser escolhidos a partir de locais aleatórios dentro de um elemento de madeira. Os corpos de prova cortados de locais pré-definidos (centro de um elemento de madeira, uma extremidade selecionada dentro de uma peça ou seções isentas de defeitos) podem ser considerados em conformidade com este requisito, desde que não produzam qualquer resultado tendencioso nas propriedades medidas.

O teor de umidade de referência, no momento do ensaio, deve ser consistente com o condicionamento em uma temperatura de $20^{\circ} \mathrm{C}$ e $65 \%$ de umidade relativa. A umidade de equilíbrio da madeira deve ser de aproximadamente $12 \%$. A temperatura de referência no momento do ensaio deve ser de $20^{\circ} \mathrm{C}$. A taxa de carga deve ser o suficiente para levar a peça à falha em cerca de um minuto. No momento do ensaio, o teor de umidade da madeira, a temperatura da madeira, e o tempo até a ruptura devem ser registrados.

Este ensaio deve ser realizado atendendo a forma, dimensões do corpo de prova e direção da carga em relação ao sentido anatômico da madeira, determinadas por norma técnica específica, como apresentadas na Figura 19. A força “F” será aumentada até $F_{u l t}$, valor no qual a o corpo de prova rompe.

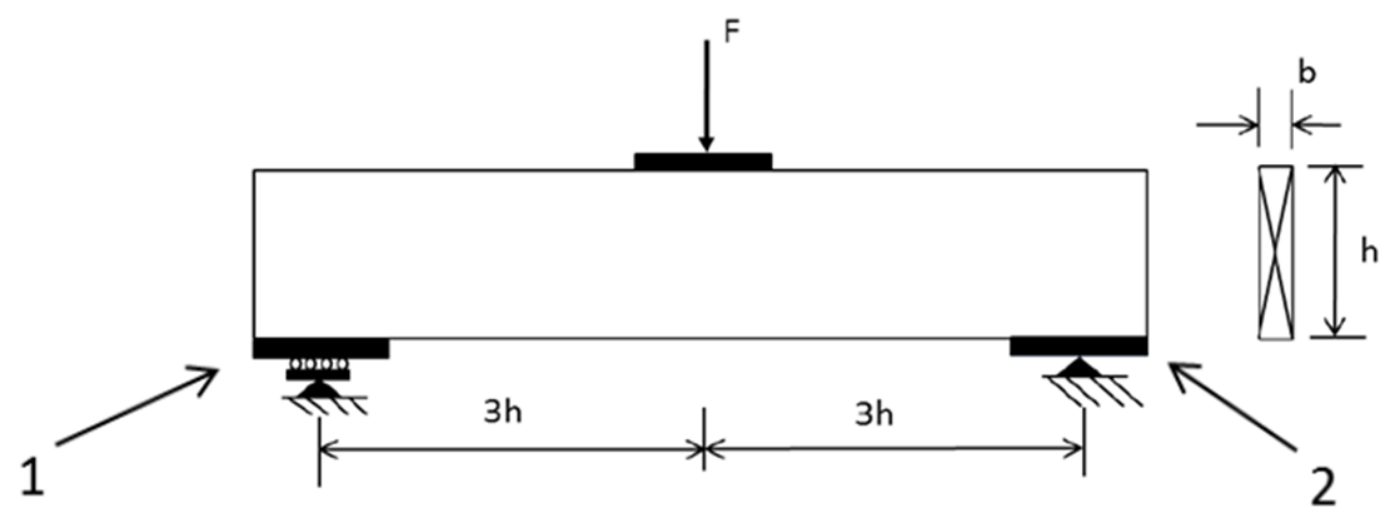

Figura 19: Esquema de ensaio para medir a resistência ao cisalhamento paralelo às fibras. Fonte: ASTM ISO 13910 (2005). 
Devem ser empregados dois tipos de apoio durante o ensaio: o primeiro, localizado à esquerda da Figura 19, é um apoio do tipo deslizante (apoio móvel), e o outro, representado pelo número "2" é um apoio fixo. As placas metálicas utilizadas entre os apoios e a peça estrutural ensaiada respeitam as dimensões da altura " $h$ " do corpo de prova e são apresentadas na Figura 20.

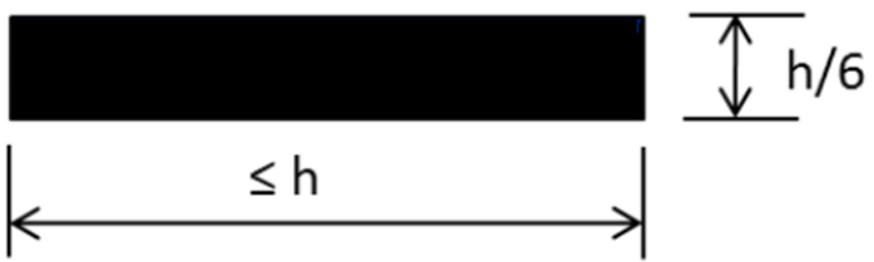

Figura 20: Dimensões das placas metálicas utilizadas no carregamento. Fonte: ASTM ISO 13910 (2005).

Segundo a norma ASTM ISO 13910:2005, algumas vigas podem apresentar modos de rupturas que não caracterizam o de cisalhamento, por exemplo, ruptura a tração paralela ou a compressão normal às fibras em peças fletidas. No entanto, todos os resultados do ensaio devem ser utilizados para avaliar as propriedades de resistência ao cisalhamento.

A partir de relações elementares da teoria clássica de resistência dos materiais, em ensaios de flexão a três pontos, para seções retangulares, o momento estático (S) ocorre no centro da seção, e a tensão de cisalhamento é expressa pela Equação 3:

$$
\tau=\frac{S . V}{I . b}
$$

Onde:

O momento estático $(\mathrm{S})$ é dado por: $S=\frac{b \cdot h \cdot h}{2.4}=\frac{b \cdot h^{2}}{8}$;

A força cortante (V) é dada por: $V=\frac{F}{2}$;

O momento de inércia (I) é dado por: $I=\frac{b \cdot h^{3}}{12}$. 
Substituindo os valores de I (momento de inércia), V (esforço cortante) e Q (momento estático), tem-se Equação 4:

$$
\tau=\frac{12 \cdot F \cdot b \cdot h^{2}}{2 \cdot 8 \cdot b^{2} \cdot h^{3}}
$$

A Equação 4, portanto, originou a equação descrita no documento normativo americano, que provêm do valor nominal da resistência ao cisalhamento de uma viga, fornecendo uma descrição normalizada da capacidade da viga. A resistência ao cisalhamento $\left(f_{v}\right)$ deve ser calculada a partir da Equação 5, neste caso:

$$
f_{v}=\frac{0,75 F_{u l t}}{b h}
$$

Onde:

$F_{u l t}:$ máxima força aplicada ao corpo de prova durante o ensaio, em $\mathrm{N}$;

bh: área da seção transversal, em mm²;

$f_{v}$ : resistência ao cisalhamento paralelo às fibras, em MPa.

A distribuição dos esforços dentro de um corpo de prova durante a realização deste tipo de ensaio, com a aplicação de uma carga central única, é demonstrada esquematicamente pela Figura 21

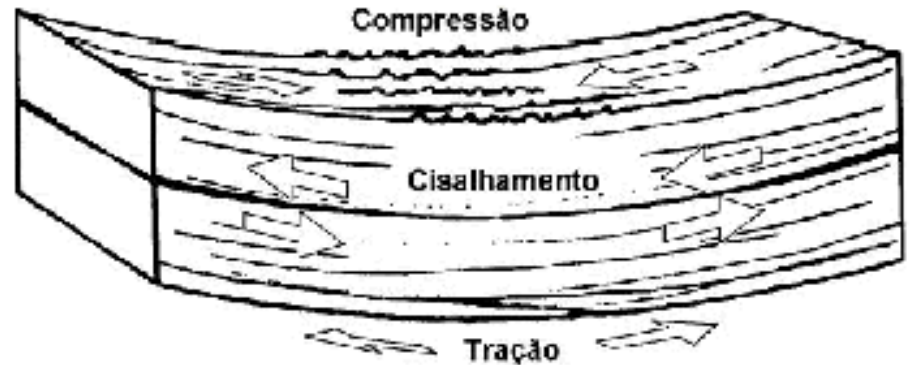

Figura 21: Distribuição de esforços durante método de ensaio ASTM ISO 13910:2005. 


\subsubsection{EUROCODE EN 408:2010}

O documento normativo EUROCODE EN 408: "Timber structures - Structural timber and glued laminated timber - Determination of some physical and mechanical properties" (2010), apresenta outro critério para determinar a resistência ao cisalhamento paralelo às fibras da madeira. Esta norma estabelece métodos para a determinação laboratorial das propriedades mecânicas da madeira em suas dimensões reais de trabalho. A determinação da densidade, da umidade e do tamanho da amostra também são definidos pelo documento normativo.

Os corpos de prova devem ser medidos com precisão de $0,01 \mathrm{~mm}$. Se a largura ou a espessura variam ao longo do corpo de prova, estas dimensões devem ser estimadas com a média aritimética de ao menos três medidas feitas na peça. Todas as medições devem ser efetuadas após o condicionamento dos corpos de prova, para o teor de umidade na ordem de $12 \%$.

O método de ensaio utilizado para determinar a resistência ao cisalhamento, neste caso, prescreve que devem ser coladas duas chapas metálicas no corpo de prova, como evidenciado na Figura 22. A espessura das chapas de aço deve ser de $10 \pm 1 \mathrm{~mm}$. Deve-se fazer uso de colas epóxi bicomponentes para ancorar as chapas ao corpo de prova. Imediatamente antes da colagem, as superfícies de ligação devem ser preparadas, as peças de madeira devem ser escovadas e as placas metálicas lixadas.

Todas as superfícies em carga devem ser cuidadosamente preparadas de modo que estejam planas e paralelas entre si, perpendiculares ao eixo do corpo de prova. Esta preparação deve ser feita após o condicionamento das madeiras. As amostras devem estar em conformidade com os requisitos indicados na Figura 22 e suas dimensões serão:

- $l=(330 \pm 2) \mathrm{mm}$;

- $\mathrm{b}=(32 \pm 1) \mathrm{mm}$;

- $\mathrm{h}=(55 \pm 1) \mathrm{mm}$. 


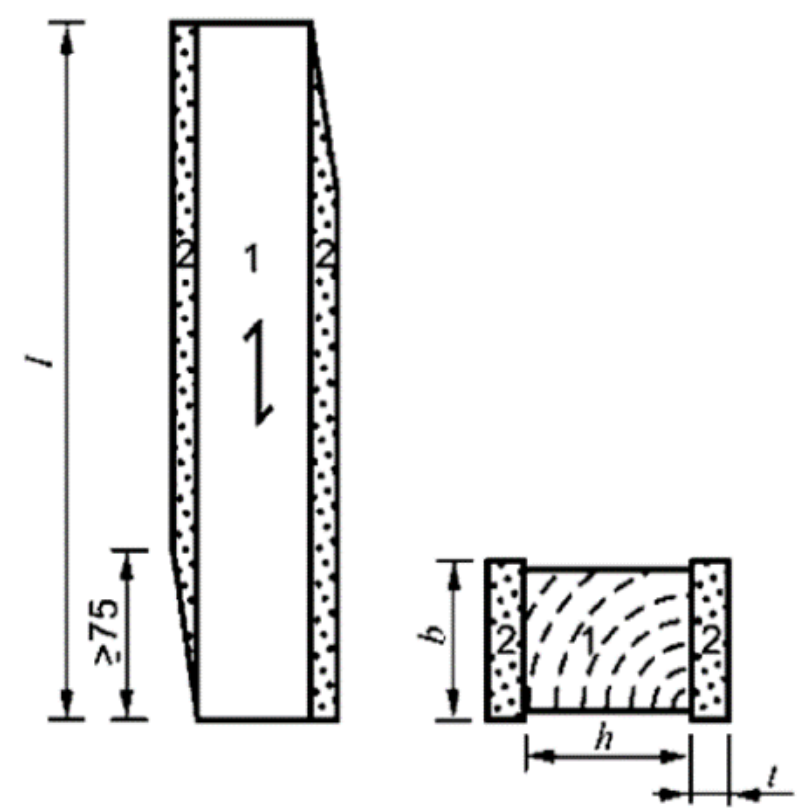

Figura 22: Corpo de prova de madeira fixado nas placas metálicas. Fonte: EUROCODE EN 408 (2010).

A amostra deve ser colocada em uma máquina de ensaios tal como mostrado na Figura 23. Deve alinhar-se de modo que seja mantido um contato permanente nos pontos de aplicação das cargas F. O ângulo entre a direção da carga e o eixo longitudinal do corpo de prova deve ser de $14^{\circ}$.

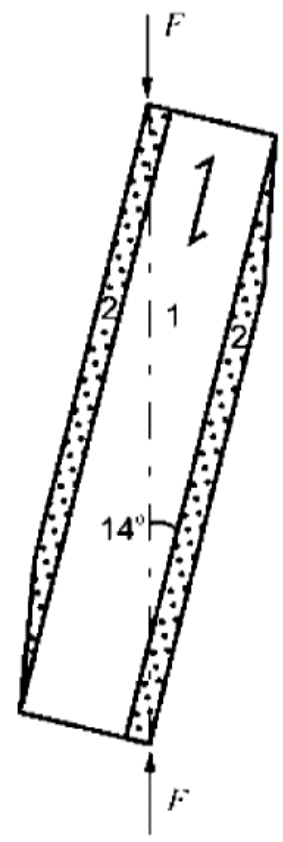

Figura 23: Procedimento de carga. Fonte: EUROCODE EN 408 (2010). 
A força $\mathrm{F}$ deve ser aplicada com uma velocidade constante e regulada de forma que a força " $F_{\text {máx }}$ " seja alcançada em $(300 \pm 120)$ s. Devem ser anotados os resultados dos corpos de prova que diferirem em mais de 120 s do valor previsto de 300s. Os tempos de ruptura devem ser registrados e seus valores médios devem ser informados. A resistência ao cisalhamento " $f_{v}$ " deve ser calculada pela Equação 6:

$$
f_{v}=\frac{F_{m a ́ x} \cdot \cos 14^{\circ}}{l}
$$

Onde:

$F_{\text {máx }}$ : máxima força aplicada ao corpo de prova durante o ensaio, em $\mathrm{N}$;

$l$ : área da seção cisalhante, em $\mathrm{mm}^{2}$;

$f_{v}$ : resistência ao cisalhamento paralelo às fibras, em MPa.

Assim como pode ocorrer nos corpos de prova recomendados pelos outros documentos normativos citados, as seções de trabalho podem variar em função da orientação de corte da madeira. Neste caso, existem três configurações possíveis para realizar a colagem das chapas metálicas, como ilustrado na Figura 24. Os corpos de prova podem apresentar orientação de corte perpendicular, tangencial, ou de aproximadamente $45^{\circ}$ em relação aos anéis de crescimento.

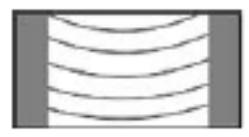

A

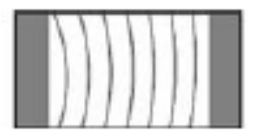

B

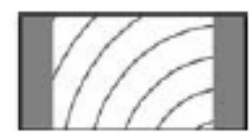

C

Figura 24: Orientação de corte da madeira em relação aos anéis de crescimento. $A$ - Corte perpendicular; B - Corte tangencial e C - Corte $45^{\circ}$. Fonte: Denzler, 2006 (Adaptada).

A seguir estão ilustrados dois exemplos de ruptura conseguida a partir do método de ensaio descrito (Figura 25 e Figura 26). Em ambos os casos pode-se observar que a orientação de corte das peças de madeira influencia na forma e na área da seção que é calculada a resistência ao cisalhamento. 


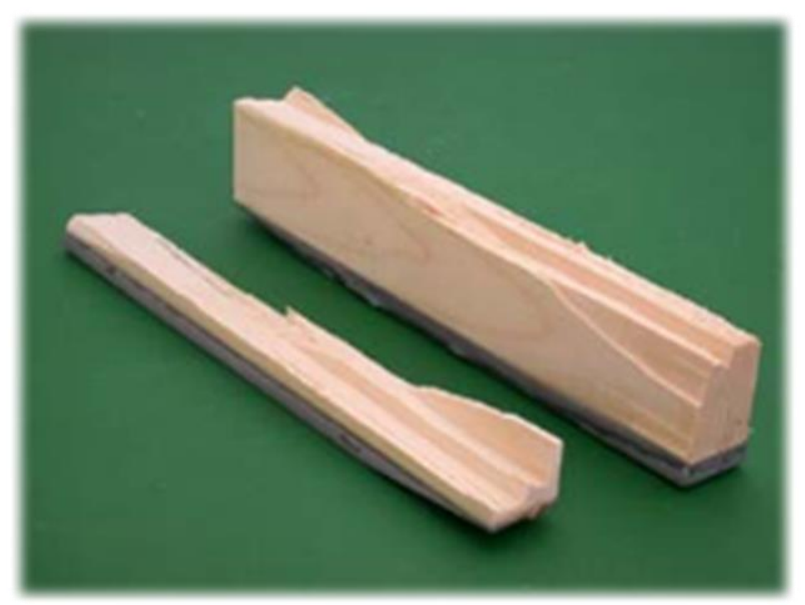

Figura 25: Orientação de corte tangencial aos anéis de crescimento da madeira. Fonte: Denzler, 2006 (Adaptada).

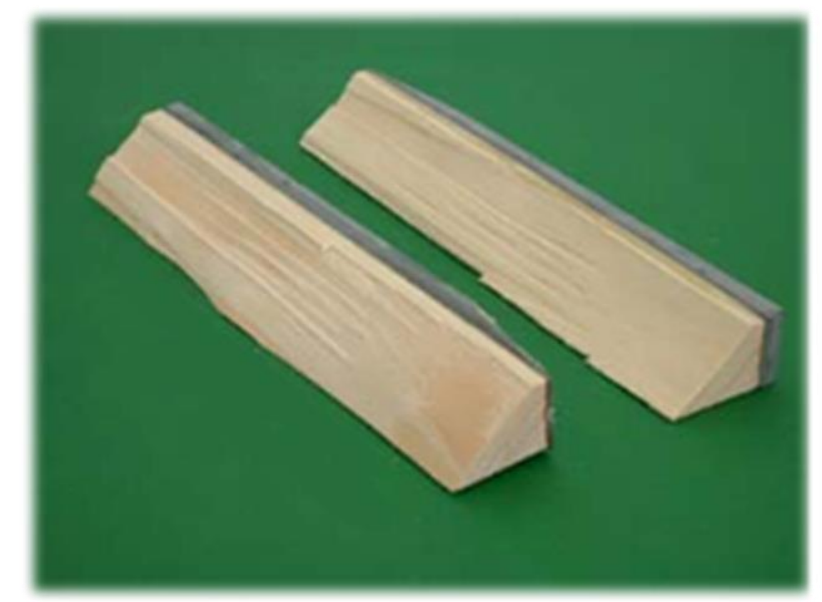

Figura 26: Orientação de corte inclinada $\left(45^{\circ}\right)$ em relação aos anéis de crescimento. Fonte: Denzler, 2006 (Adaptada).

\subsection{Contribuições de outros pesquisadores}

Sales (1996), em sua tese de Doutorado, utilizou o método de ensaio descrito no documento normativo nacional que passou a ter vigência em 1997 para, dentre outras propriedades, investigar a resistência ao cisalhamento paralelo às fibras de seis espécies de Pinus (Pinus caribaea var. caribaea, Pinus caribaea var. bahamensis, Pinus caribaea var. hondurensis, Pinus elliotti var. elliotti, Pinus oocarpa e Pinus taeda) e a resistência ao cisalhamento média $\left(f_{\mathrm{v} 0, \mathrm{~m}}\right)$, que variou de 6,9 a 8,0 MPa. 
Riyanto (1998) utilizou quatro métodos de ensaio diferentes para determinar a resistência ao cisalhamento em peças de madeira. Foram comparados ensaios de flexão, um método de torção e o método de corte simples, similar ao utilizado atualmente no Brasil. Segundo o pesquisador, o teste de flexão de três pontos foi um método de teste bom para determinar a resistência ao cisalhamento de madeira estrutural, porque este teste utiliza uma configuração simples, que se aproxima das aplicações reais.

Bortoletto Jr. e Rocco Lahr (2000), visando contribuir para o uso da madeira de Pinus na construção civil, apresentam resultados que envolvem valores médios de resistência ao cisalhamento paralelo às fibras, e neste caso, os valores calculados estão compreendidos entre 11,4 e 13,4 MPa.

Santini (2000) realizou uma análise comparativa entre Pinus elliotti, Pinus taeda e Araucaria angustifolia, promovendo ensaios com 30 corpos de prova de cada espécie e níveis de umidade da ordem de $12 \%$. Segundo o autor, os resultados foram bastante satisfatórios, sendo que os valores médios da resistência ao cisalhamento foram 8,5 $\mathrm{MPa}$ para o P. elliotti e 8,7 MPa para o P. taeda e ligeiramente maiores para a Araucaria angustifolia, 9,1 MPa.

Denzler (2006) realizou ensaios segundo preconiza o documento normativo europeu EN 408:2010. Dos 372 corpos de prova ensaiados, o autor constatou que 260 destes não apresentavam defeitos de crescimento, como: fissuras, nós, presença de medula e outros. $\mathrm{O}$ pesquisador teve problemas com a aderência na interface madeira/chapa metálica. $\mathrm{O}$ adesivo sugerido pelo documento normativo não foi suficientemente ancorado. A partir destas observações concluiu que devido a problemas observados ao usar esta configuração de ensaio os resultados não foram compatíveis com os valores de resistência ao cisalhamento encontrados na literatura.

Ido (2010) mostrou que, ao realizar ensaios de resistência ao cisalhamento paralelo às fibras pelo método proposto pela norma ASTM ISO 13910:2005, as amostras tenderam a apresentar falhas por flexão, em vez de ruptura por cisalhamento.

Silva (2013) conseguiu um ganho nos valores de resistência ao cisalhamento em corpos de prova de Pinus taeda após o tratamento de termorretificação. Os valores que in natura estavam próximos de $8 \mathrm{MPa}$, alcançaram $10 \mathrm{MPa}$ após realizado o tratamento à temperatura de $180^{\circ} \mathrm{C}$ e 30 minutos de exposição. O mesmo autor salienta que a ação do calor provoca alterações na madeira e, as propriedades mecânicas podem aumentar ou diminuir, dependendo do programa de tratamento térmico adotado. 
Trianoski et al.(2014) realizou ensaios de resistência ao cisalhamento segundo a norma da Comissão Panamericana de Normas Técnicas (COPANT), criada em 1972, baseada nas premissas da ASTM, com sete espécies de Pinus tropicais: P. caribaea var. bahamensis, $P$. caribaea var. caribaea, P. caribaea var. hondurensis, P. chiapensis, P. maximinoi, P. oocarpa e P. tecunumanii. Os resultados médios obtidos foram: 10,64, 9,10, 10,49, 8,72, 11,37, 11,95 e 11,42 MPa respectivamente.

\subsection{Principais conclusões da revisão bibliográfica}

Realizada esta revisão, foi possível verificar que a madeira de Pinus spp. possui um enorme potencial para a construção civil. Muitos são os pesquisadores que colaboraram para o desenvolvimento de técnicas de ensaio e caracterização desta madeira que, pelo fato de ser proveniente de florestas manejadas, de rápido crescimento e com características diferentes daquelas espécies nativas, necessitam de métodos de ensaios diferenciados para que sua aplicação seja mais coerente com suas características tendo em vista o apelo para segurança do material.

Visto que, dentre os ensaios e métodos pesquisados até então, nenhum se aprofundou na técnica de cisalhamento prescrita pela normalização ASTM ISO 13910:2005. Esta pesquisa teve por objetivo testar a madeira de Pinus com a referida norma. 


\section{MATERIAIS E MÉTODOS}

Nesta seção são fornecidas as informações referentes aos materiais e métodos utilizados neste trabalho. Os ensaios foram executados no Laboratório de Madeiras e Estruturas de Madeira (LaMEM), do Departamento de Engenharia de Estruturas (SET), da Escola de Engenharia de São Carlos (EESC), da Universidade de São Paulo (USP). O laboratório dispõe de todos os equipamentos necessários para caracterização das propriedades físico-mecânicas de madeira.

\subsection{Materiais}

Para a realização desta pesquisa foram utilizadas tábuas de madeiras coníferas de Pinus spp. da região Sul do País, mais precisamente dos Estados do Paraná e Santa Catarina. As tábuas passaram por um rigoroso processo de usinagem, secagem e classificação não destrutiva, oriundas do processo industrial da empresa Berneck S. A. Painéis e Serrados, localizada na cidade de Curitibanos/PR. As tábuas são apresentadas na Figura 27.

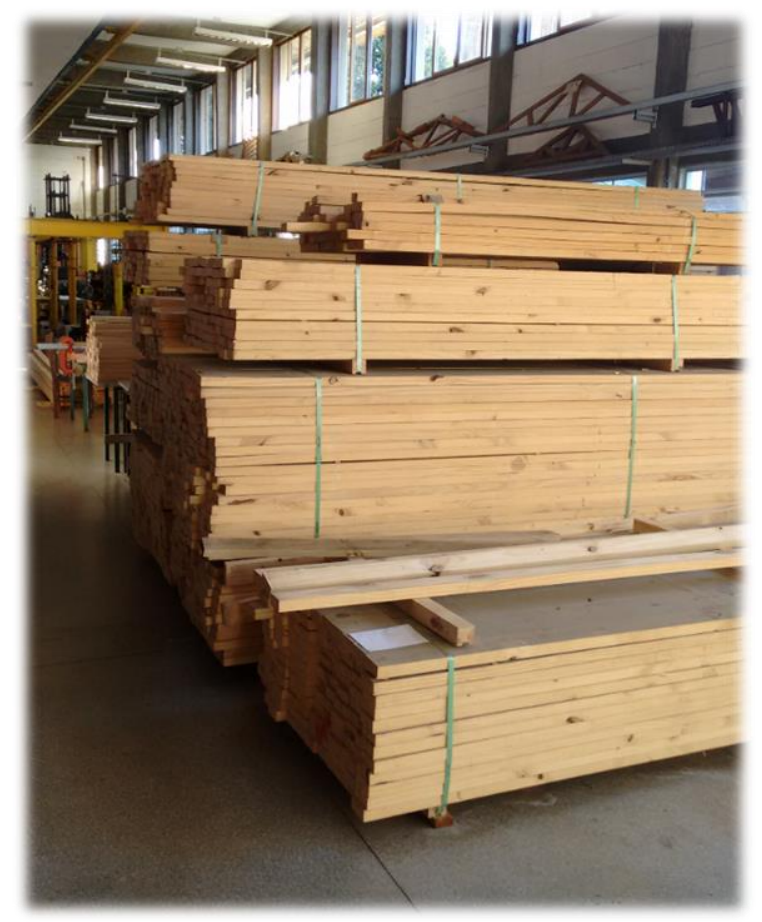

Figura 27: Lote de madeira de Pinus spp. fornecidos pela Berneck S.A. Fonte: o Autor. 
De um lote de 2600 peças, foram selecionadas aleatoriamente 40 tábuas, número mínimo exigido pela norma ASTM ISO 13910:2005 para caracterização de propriedades de resistência. Estas tábuas tinham dimensões aproximadas de 40x 90x4000mm e teor de umidade da ordem de $12 \%$.

\subsection{Métodos}

As propriedades analisadas na presente pesquisa foram escolhidas em função de aspectos observados na revisão de literatura. Os valores obtidos para resistência ao cisalhamento paralelo às fibras, além da variabilidade intrínseca do material, sofrem uma série de interferências devidas à metodologia de ensaio utilizada, principalmente no que se refere à forma e dimensões do corpo de prova.

O processo de usinagem e execução de corpos de prova foi realizado nos equipamentos da oficina do LaMEM, que conta com duas serras circulares, uma serra fita, uma desengrossadeira, uma desempenadeira, uma tupia, uma lixadeira, um torno, uma furadeira de bancada, uma furadeira comum, ferramentas comuns e outros equipamentos.

As dimensões dos corpos de prova foram determinadas utilizando paquímetro digital com sensibilidade de 0,01 mm (Figura 28), e as massas foram determinadas utilizando uma balança analítica. O teor de umidade dos corpos de prova foi aferido através de um medidor elétrico, modelo M52, da marca MARRARI ${ }^{\circledR}$ (Figura 29). Foram empregados também equipamentos de medição mais simples, réguas, trenas, dentre outros.

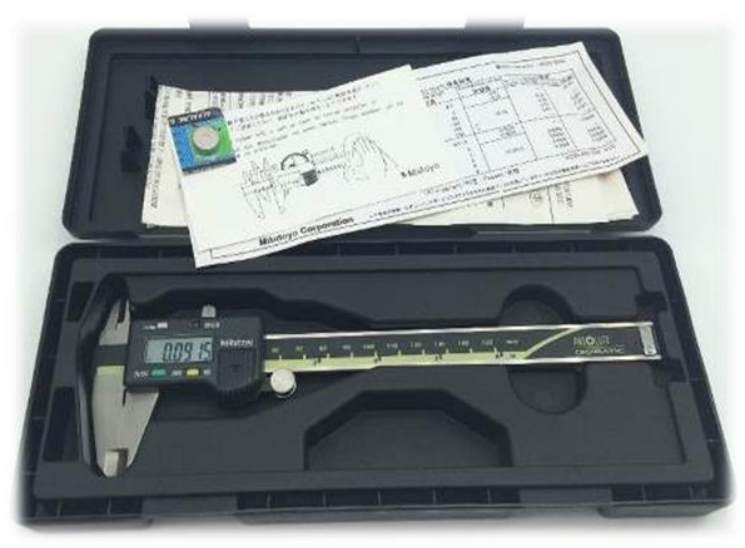

Figura 28: Paquímetro digital.

Fonte: o Autor. 


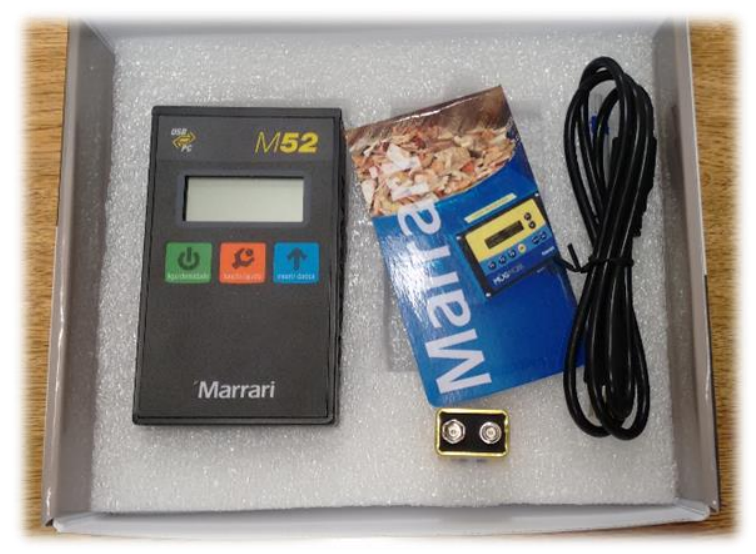

Figura 29: Medidor elétrico de umidade M52. Fonte: o Autor.

Na condução dos testes de resistência foi utilizada a máquina universal de ensaios da marca AMSLER ${ }^{\circledR}$, com capacidade de carregamento de $250 \mathrm{kN}$, ilustrada na Figura 30.

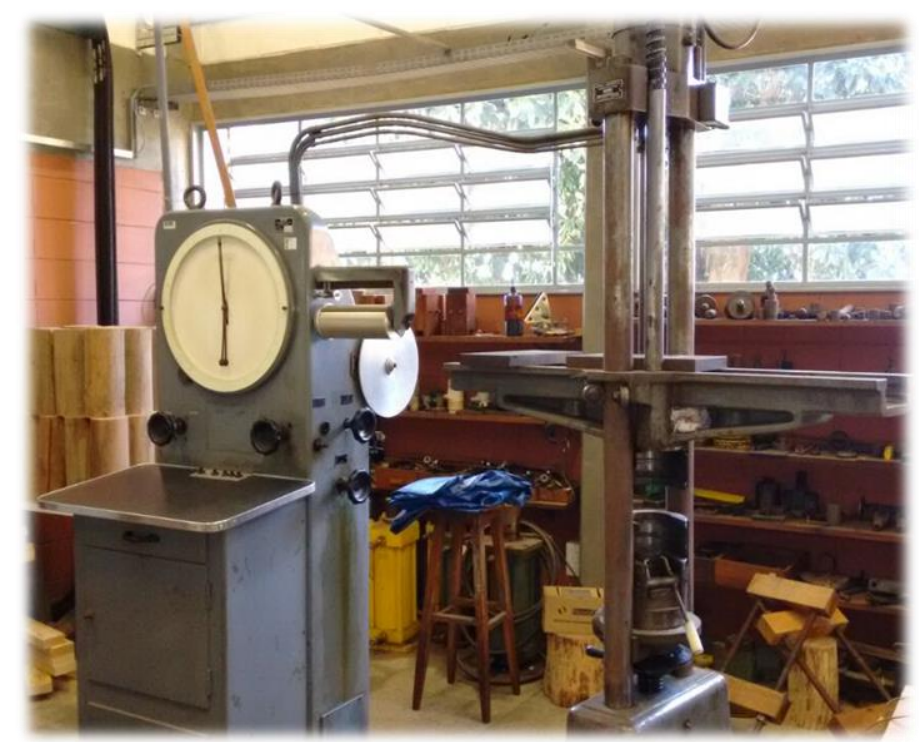

Figura 30: Máquina universal de ensaios AMSLER ${ }^{\circledR}$. Fonte: o Autor.

\subsubsection{Procedimentos Experimentais}

O primeiro procedimento a ser realizado foi a classificação visual das tábuas. A classificação visual serviu para prever quais peças teriam melhor desempenho quando solicitados a esforços mecânicos. Houve uma separação por classes de qualidade segundo 
Southern Pine Inspection Bureau (SPIB), levando-se em conta apenas a quantidade e tamanho dos nós. Outros defeitos como arqueamento, distorção das fibras, arqueamento, torcimento, presença de medula, esmoados, fungos e insetos não foram observados nas peças fornecidas pela empresa.

Concluída a classificação visual, as tábuas selecionadas passaram por uma pesagem simples. Aproveitou-se o processo de pesagem para medir também a umidade com o medidor elétrico. Foram feitas as medições necessárias para calcular o volume de cada tábua, e, por consequência disto, foi calculada a densidade aparente do lote.

A densidade foi calculada segundo as orientações do Anexo B da ABNT NBR 7190:1997 - "Determinação das Propriedades das Madeiras para Projetos Estruturais". A massa das peças de madeira com teor de umidade da ordem de $12 \%$ foi dividida pelo volume das mesmas, e usou-se a média aritmética para chegar no valor da massa especifica, que foi de $470 \mathrm{~kg} / \mathrm{m}^{3}$.

Elaborou-se um gabarito para serem efetuados os cortes dos corpos de prova. A tábua com comprimento inicial de 4000mm foi seccionada ao meio e de uma das parcelas foram retirados os corpos de prova de cisalhamento paralelo às fibras.

Efetuaram-se ensaios em corpos de prova de madeira maciça com a finalidade de estabelecer os valores de resistência ao cisalhamento segundo diferentes métodos. Os ensaios para determinação das propriedades foram conduzidos de acordo com as recomendações do anexo B da ABNT NBR 7190:1997, segundo o documento normativo norte americano ASTM ISO 13910:2005 "Structural timber - Characteristic values of strength-graded timber Sampling, full-size testing and evaluation" e também de acordo com o código de métodos europeu EUROCODE EN 408:2010 “Timber structures - Structural timber and glued laminated timber - Determination of some physical and mechanical properties”. Para cada método foram confeccionados 40 corpos de prova e um corpo de prova para estimar a carga aplicada nos demais.

Os ensaios mecânicos seguiram a ordem citada acima, sendo que os primeiros testes foram executados sob as premissas do documento normativo nacional. Os corpos de prova apresentavam formato e dimensões nominais conforme ilustra a Figura 31. 


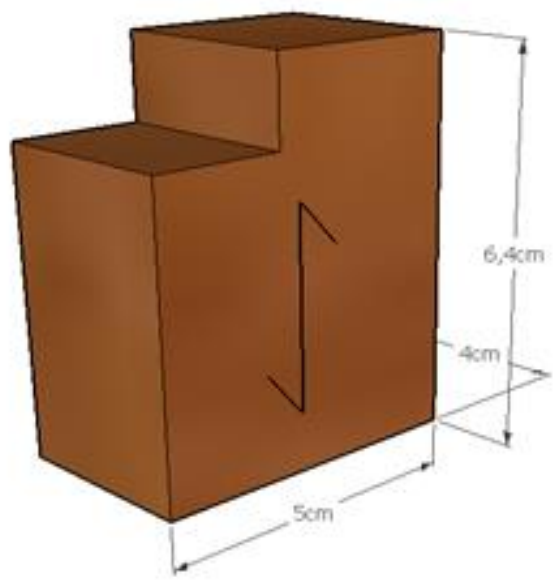

Figura 31: Corpo de prova modelo ABNT NBR 7190:1997. Fonte: o Autor.

As dimensões dos corpos de prova empregados nos testes de cisalhamento puro foram reduzidos em relação às dimensões estabelecidas pela ABNT NBR 7190:1997. Tal adaptação foi adotada devido a limitação em relação a espessura das tábuas fornecidas pela empresa Berneck S.A.. O documento normativo assume a hipótese de que a simples redução de área não prejudica os resultados de cisalhamento.

Os detalhes do dispositivo de ensaio de cisalhamento bem como um dos corpos de prova ensaiados são apresentados na Figura 32. Após a ruptura, a área cisalhada dos corpos de prova utilizados neste ensaio tem um aspecto irregular, não homogêneo, similar ao apresentado na Figura 33.

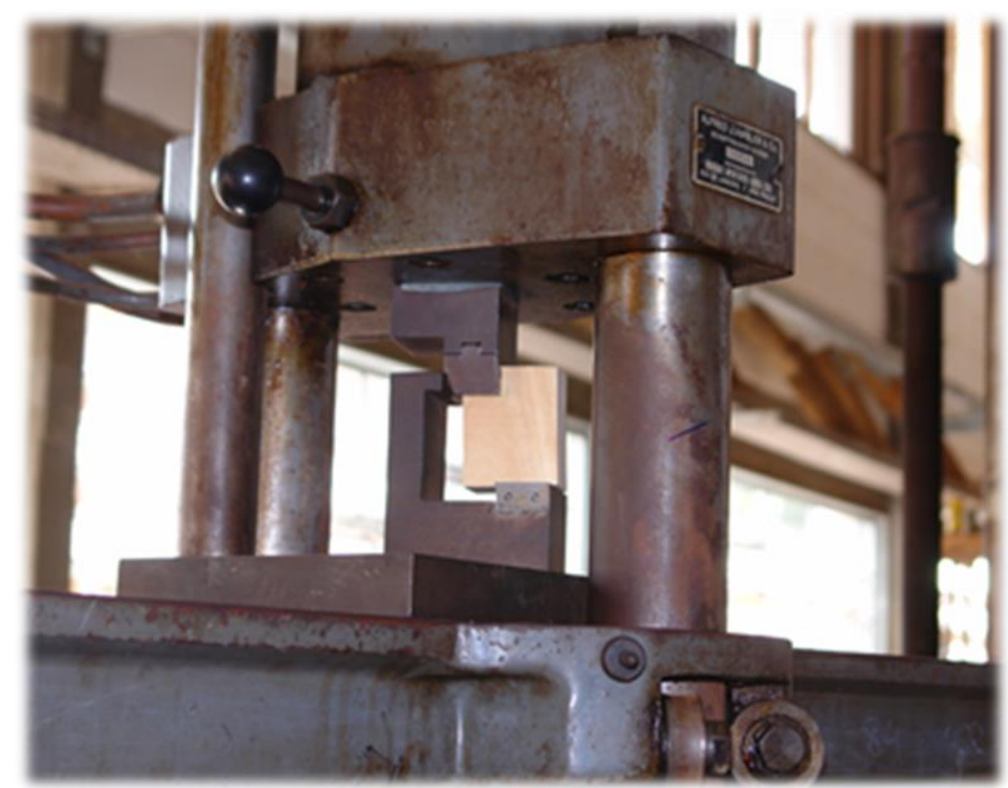

Figura 32: Arranjo de ensaio segundo a ABNT NBR 7190:1997. Fonte: o Autor. 


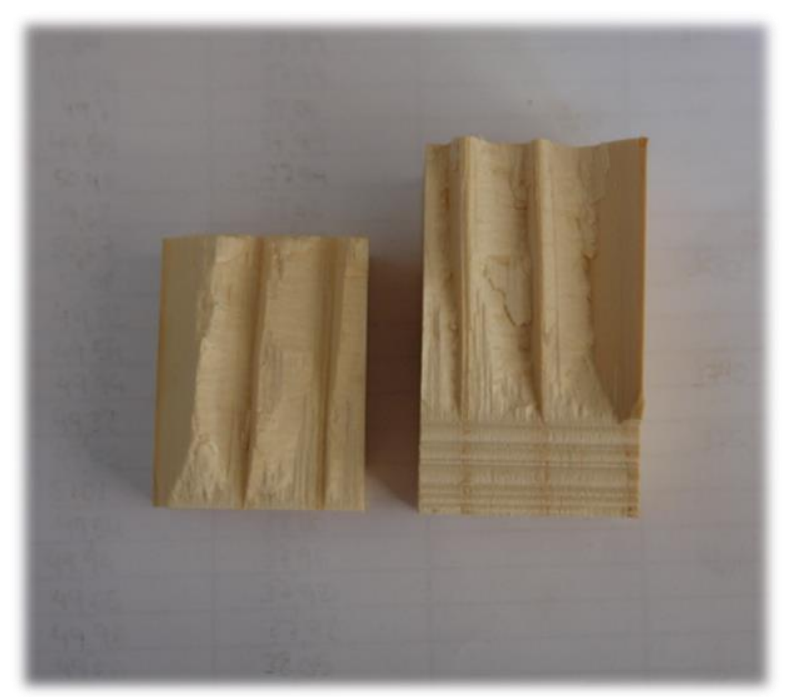

Figura 33: Detalhe da ruptura em corpo de prova no modelo da ABNT NBR 7190:1997. Fonte: o Autor.

O segundo método de ensaio utilizado foi proposto pelo documento normativo norte americano ASTM ISO 13910:2005. Os corpos de prova apresentaram, neste caso, forma prismática de seção retangular com dimensões nominais de 40x75 mm, e comprimento ao longo das fibras de $525 \mathrm{~mm}$, definido com base na altura do corpo de prova, de acordo com os procedimentos e premissas de cálculo da norma. O procedimento de ensaio é evidenciado pela Figura 34.

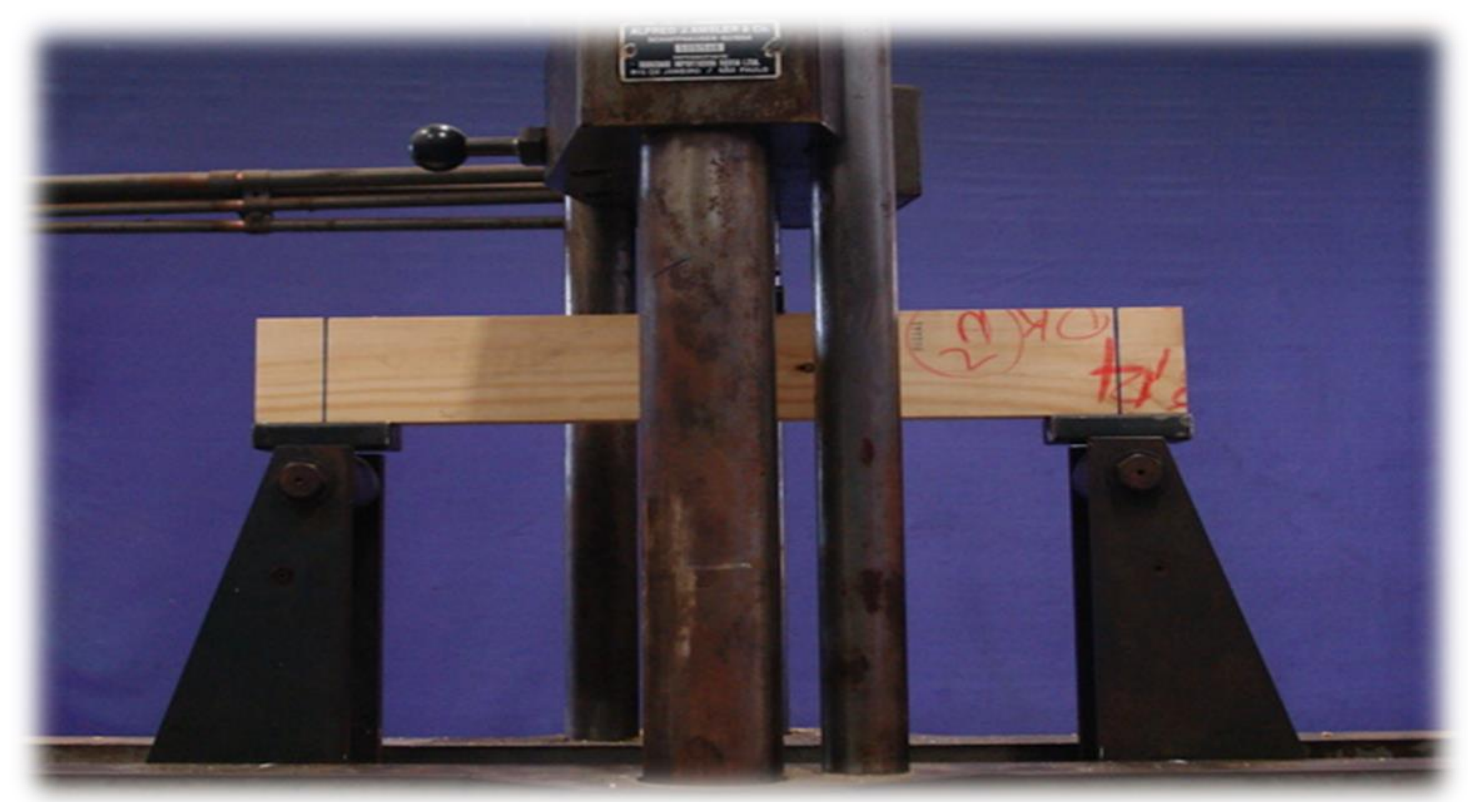

Figura 34: Arranjo de ensaio segundo a ASTM ISO 13910:2005.

Fonte: o Autor. 
O procedimento de ensaio faz uso de um arranjo similar ao ensaio de flexão simples. Em um corpo de prova de dimensões de seção transversal estruturais, registram-se que os esforços tangenciais de cisalhamento podem ocasionar o colapso das peças. Seguem algumas ilustrações que evidenciam a ruptura dos corpos de prova por cisalhamento paralelo às fibras (Figura 35).
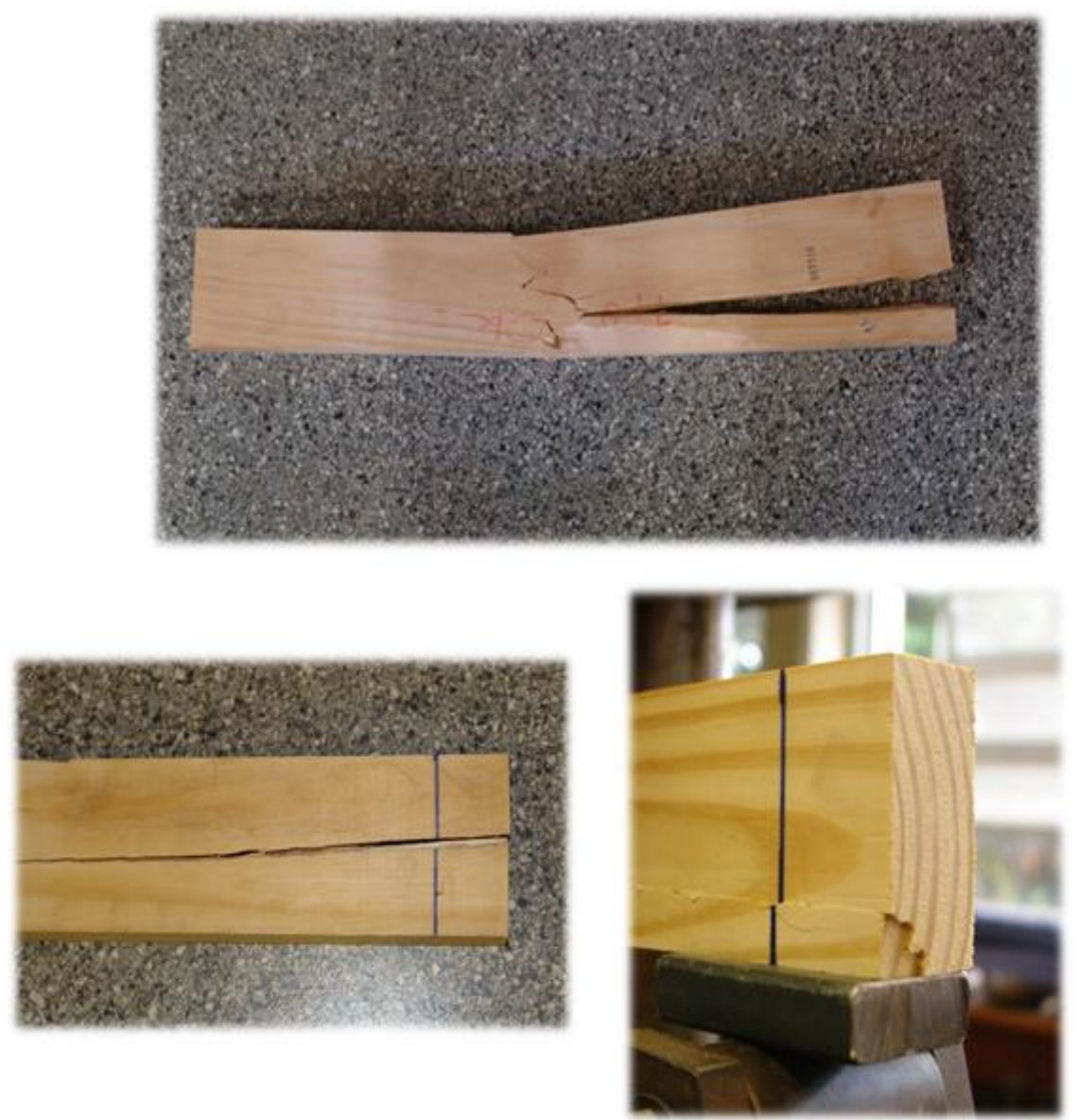

Figura 35: Detalhes de algumas rupturas em corpos de prova ASTM ISO 13910:2005. Fonte: o Autor.

Para o método proposto pelo EUROCODE EN 408:2010 foram elaborados dois tipos de dispositivos metálicos com a finalidade de executar o ensaio de forma que o ângulo requerido pelo documento fosse mantido, como mostra a Figura 36. 

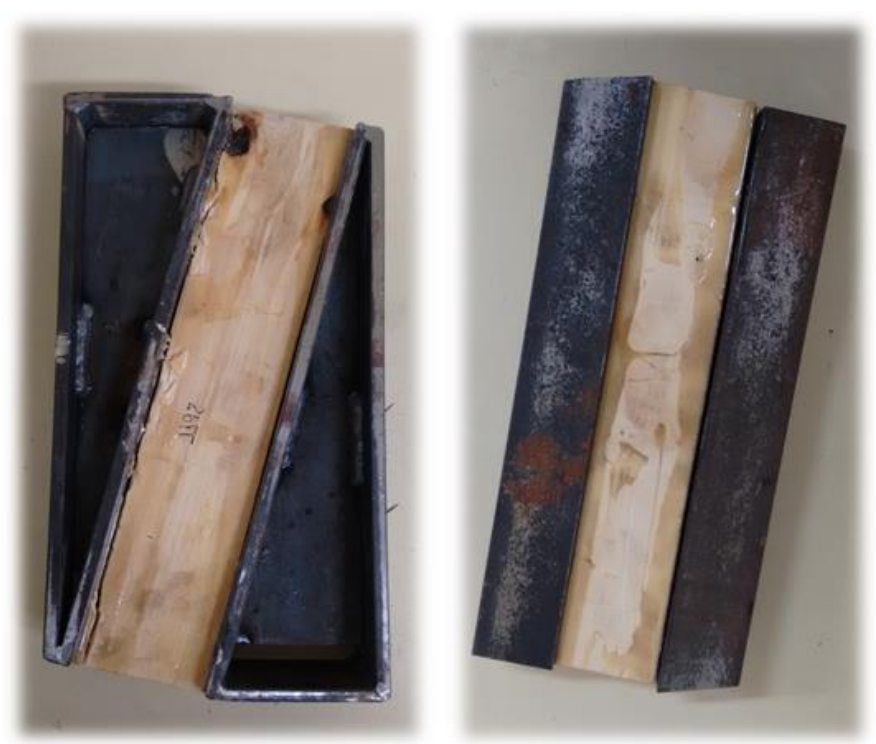

Figura 36: Tipos de dispositivos elaborados para executar o ensaio. Fonte: o Autor.

A Figura 37 apresenta uma das tentativas de realizar o ensaio segundo o método de ensaio proposto pelo EUROCODE EN 408:2010. Observa-se que a inclinação requerida pelas premissas do documento normativo durante a execução do ensaio. No entanto, a colagem não foi eficiente e a resistência ao cisalhamento das peças foi superior a aderência entre o adesivo e o dispositivo.

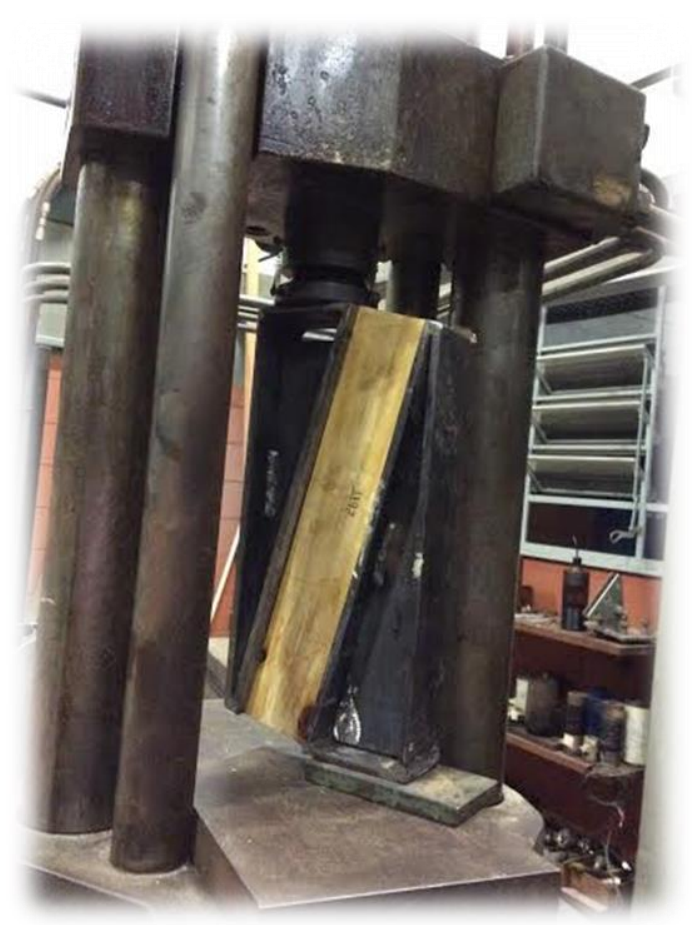

Figura 37: Arranjo de ensaio segundo o EUROCODE EN 408:2010. Fonte: o Autor. 
Apesar de ter sido feito o uso de um adesivo bi-componete indicado pelo documento normativo, em ambos os dispositivos a adesão entre a cola e a peça metálica não foi suficiente para garantir a ruptura por cisalhamento no material madeira, sendo que, neste caso, a ruptura ocorreu destacamento da peça metálica na interface do dispositivo, assim como apresentado por Denzler (2006) na revisão de literatura. Foram respeitados os tempos de cura do adesivo e as pressões necessárias foram empregadas para realizar a colagem. A Figura 38 apresenta o adesivo utilizado e a Figura 39 ilustra o destacamento quase completo em um dos dispositivos utilizados.
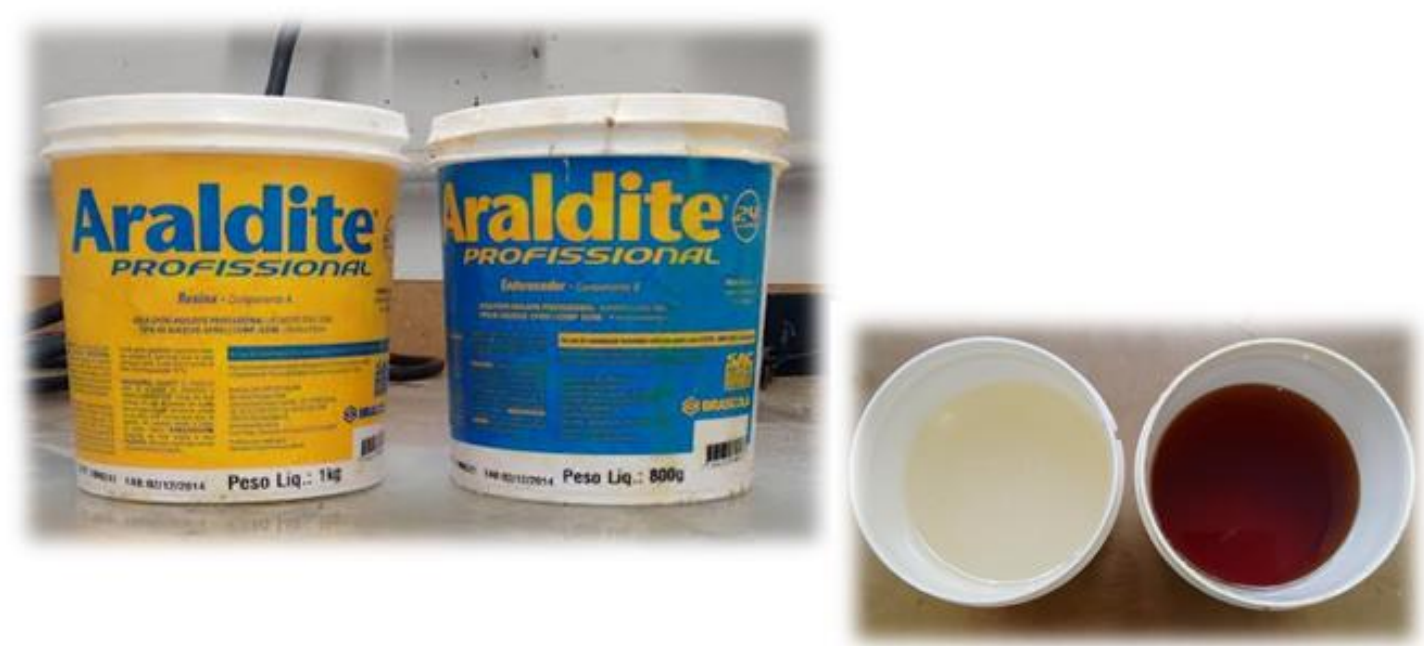

Figura 38: Adesivo utilizado na colagem.

Fonte: o Autor.

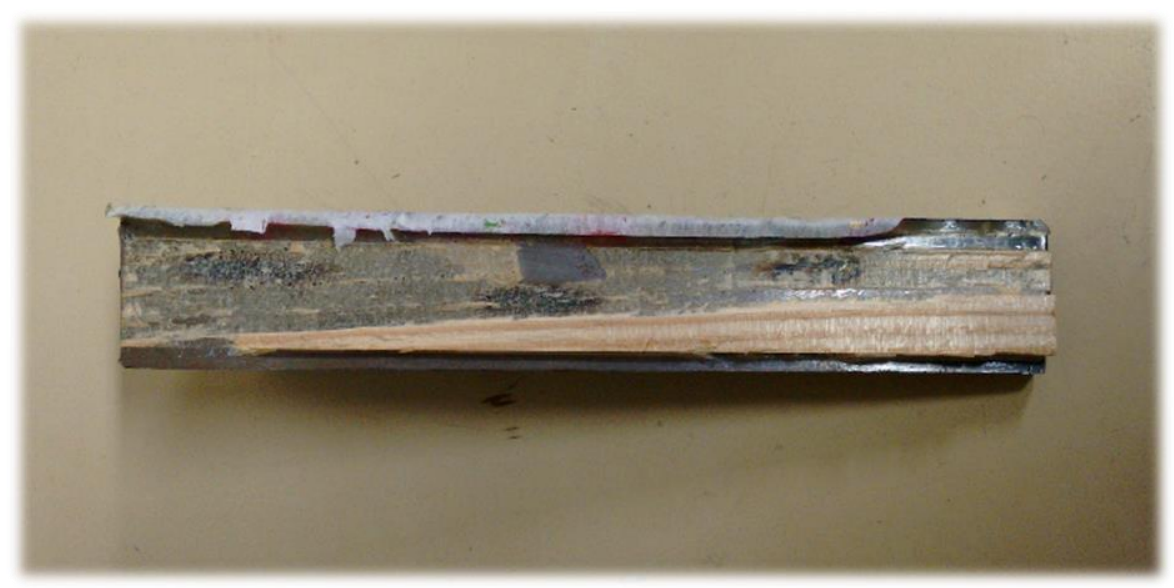

Figura 39: Detalhe do destacamento na interface adesivo/dispositivo metálico. Fonte: o Autor. 


\subsubsection{Análise Estatística}

Para comprovar a não equivalência nas formas de medida dos valores da resistência ao cisalhamento $\left(f_{v, 0}\right)$ pelas normas ABNT NBR 1790:1997 $\left(f_{v-a b}\right)$ e ASTM ISO 13910:2005 $\left(f_{v-}\right.$ iso), realizou-se uma análise de variância (ANOVA) não paramétrica de Kruskal-Wallis, com o auxílio do software BioEstat@, versão 5.3.

Constatada a não equivalência entre os valores de resistência ao cisalhamento pelas duas abordagens de cálculo distintas, o método dos mínimos quadrados foi utilizado para obtenção do coeficiente ótimo $(\lambda)$ da relação entre os valores de resistência $\left(f_{v-i s o}=\lambda \cdot f_{v-a b}\right)$. A obtenção do coeficiente ótimo $(\lambda)$ se deu pela minimização da Equação 7, obtido com o auxílio do método de Newton com aproximação quadrática (Equação 8), ficando a convergência para solução ótima independente da escolha da estimativa inicial $\left(\lambda_{0}\right)$ do método iterativo.

$$
\begin{aligned}
& f(\lambda)=\frac{1}{2} \cdot \sum_{i=1}^{n}(f v-\text { iso }-\lambda \cdot f v-a b)^{2} \\
& \lambda=\lambda_{o}-\left(\frac{d^{2}}{d \lambda^{2}}\left[f\left(\lambda_{o}\right)\right]\right)^{-1} \cdot \frac{d}{d \lambda}\left[f\left(\lambda_{o}\right)\right]
\end{aligned}
$$

Além do coeficiente ótimo $(\lambda)$ obtido entre as variáveis $f v$-iso e $f v$-ab pelo método dos mínimos quadrados, modelos de regressão a dois parâmetros (Tabela 4) foram utilizados como forma de verificar a possibilidade de se estimar os valores da resistência ao cisalhamento na flexão conhecidos os valores da resistência o cisalhamento obtidos pela norma brasileira.

Tabela 4: Modelos de regressão utilizados na estimativa de fv-iso.

\begin{tabular}{cc}
\hline \hline Tipo de Ajuste & Função $[\boldsymbol{Y}=\boldsymbol{f}(\boldsymbol{X})]$ \\
\hline Polinomial Linear [Lin] & $Y=a+b \cdot X$ \\
Exponencial [Exp] & $Y=a \cdot e^{b \cdot X}$ \\
Logarítmica [Log] & $Y=a+b \cdot \operatorname{Ln}(X)$ \\
Geométrica [Geo] & $Y=a \cdot X^{b}$ \\
\hline \hline
\end{tabular}


Os modelos de regressão também foram testados com o auxílio da ANOVA (Tabela 4), sendo $X$ a variável dependente, $Y$ a variável independente e $a$ e $b$ as constantes (parâmetros) das funções ajustadas pelo método dos mínimos quadrados. Pela ANOVA dos modelos de regressão, avaliados também ao nível de significância de 5\%, a hipótese nula estipulada consistiu na não representatividade dos modelos testados $\left(H_{0}: \beta=0\right)$, e na representatividade como hipótese alternativa $\left(H_{1}: \beta \neq 0\right)$. P-valor superior ao nível de significância considerado implica em aceitar $H_{0}$ (o modelo testado não é representativo - variações de $X$ são incapazes de explicar as variações em $Y$ ), refutando-a em caso contrário (o modelo testado é representativo). Além do uso da ANOVA, que permite aceitar ou não a representatividade dos modelos testados, os valores do coeficiente de determinação $\left[\mathrm{R}^{2}\right]$ foram obtidos como forma de avaliar a capacidade das variações da variável independente $X$ em explicar a variável preditiva $Y$, possibilitando eleger, dentre os modelos considerados significativos, o de melhor ajuste por relação testada. 


\section{RESULTADOS E DISCUSSÕES}

\subsection{Apresentação dos Resultados Experimentais}

A Tabela 5 apresenta os valores médios $(\bar{x})$, os coeficientes de variação $(C V)$, os menores (Mín) e os maiores (Máx) valores das resistências ao cisalhamento obtidos por ambas as normas investigadas.

Tabela 5: Estatísticas descritivas dos valores da resistência ao cisalhamento.

\begin{tabular}{ccc}
\hline Estat. & $\mathbf{f}_{\mathbf{v} \text {-ab }}(\mathbf{M P a})$ & $\mathbf{f}_{\mathbf{v} \text {-iso }}(\mathbf{M P a})$ \\
\hline $\bar{x}$ & 9,04 & 4,86 \\
CV $(\%)$ & 24,21 & 19,20 \\
Mín. & 2,97 & 3,21 \\
Máx. & 12,49 & 8,08 \\
\hline
\end{tabular}

Os valores médios correspondentes à resistência ao cisalhamento paralelo às fibras, permitem a observação de que a variação dos valores foi dada pelo método de ensaio utilizado. A variação entre os dois ensaios para a espécie estudada tiveram diferenciação bastante discrepante. Os resultados obtidos com corpos de prova isentos de defeitos produzidos com Pinus spp. apresentaram diferença considerável, sendo, o valor calculado para o corpo de prova isento de defeitos, por volta de duas vezes maior que para o corpo de prova estrutural.

Os valores médios calculados a partir dos ensaios que seguiram as premissas da ABNT NBR 7190:1997 ficaram próximos aos valores médios apresentados na revisão de literatura. No entanto, os valores médios correspondentes aos ensaios realizados com o documento normativo ASTM ISO 13910:2005 foram aquém dos resultados apresentados em outros trabalhos.

Mesmo sendo os corpos de prova provenientes da mesma tábua, a variação de resistência obtida em relação à espécie ensaiada pode ser explicada pela diferença de propriedades anatômicas segundo o sentido de aplicação da carga, e também pela presença ou não de defeitos. O método de ensaio brasileiro pode fornecer resultados mais elevados devido a presença de elementos de raio. 
Os valores característicos $\left(\mathrm{f}_{\mathrm{v}, \mathrm{k} \text {-ab }}\right.$ e $\left.\mathrm{f}_{\mathrm{v}, \mathrm{k} \text {-iso }}\right)$ foram calculados segundo as proposições de cada documento normativo. A Tabela 6 apresenta os valores característicos para a resistência ao cisalhamento paralelo às fibras. $\mathrm{O}$ valor tomado como característico para os ensaios $\mathrm{ABNT}$ NBR 7190:1997 foi igual a 0,7 da média dos valores apresentados nos ensaios.

Tabela 6: Valores característicos de resistência ao cisalhamento paralelo às fibras.

\begin{tabular}{lr}
\hline \hline \multicolumn{2}{c}{ Valores característicos (MPa) } \\
\hline $\mathrm{f}_{\mathrm{v}, \mathrm{k}-\mathrm{ab}}$ & 6,40 \\
$\mathrm{f}_{\mathrm{v}, \mathrm{k} \text {-iso }}$ & 3,14 \\
\hline
\end{tabular}

Os valores característicos apresentados permitem a observação de que a variação dos também pode ser proveniente do método de ensaio utilizado, sendo novamente, o valor calculado para o corpo de prova isento de defeitos, por volta de duas vezes maior que para o corpo de prova estrutural.

O P-valor obtido da ANOVA de Kruskal-Wallis foi inferior a 0,000 (P-valor<0,05), evidenciando as diferenças significativas entre as formas de obtenção da resistência ao cisalhamento. Isso implica que os valores da norma brasileira são significativamente superiores (86\%) aos valores da resistência ao cisalhamento provenientes do uso da norma ASTM ISO 13910:2005, justificado possivelmente pela presença de elementos transversais como células de raio nos corpos de prova do modelo ABNT NBR 7190:1997 ou ainda pela presença onerosa de defeitos de crescimento como nós nos elementos estruturais ensaiados seguindo o documento americano.

O coeficiente ótimo $(\lambda)$ obtido da relação entre os valores da resistência ao cisalhamento $\left(f_{v-i s o}=\lambda \cdot f_{v-a b}\right)$ foi igual a 0,52 , e a relação entre os valores da resistência ao cisalhamento é expressa por $f_{v-i s o}=0,52 \cdot f_{v-a b}$.

A Tabela 7 apresenta os resultados dos modelos de regressão da estimativa dos valores da resistência ao cisalhamento obtidos pela norma ASTM ISO 13910:2005 em função dos valores da resistência ao cisalhamento obtidos da norma brasileira ABNT NBR 7190:1997.

Tabela 7: Modelos de regressão utilizados na estimativa dos valores da resistência ao cisalhamento na flexão em função dos valores da resistência ao cisalhamento direto.

\begin{tabular}{cccccc}
\hline \hline $\boldsymbol{X}=\boldsymbol{f}_{\boldsymbol{v} \text { - } \boldsymbol{a} \boldsymbol{b} ; \boldsymbol{Y}=\boldsymbol{f}_{\boldsymbol{v} \text {-iso }}}$ & \multicolumn{4}{c}{ Parâmetros } \\
\cline { 1 - 4 } Modelos & $\boldsymbol{a}$ & $\boldsymbol{b}$ & $\mathbf{R}^{\mathbf{2}}$ & P-valor \\
\hline$Y=a+b \cdot X$ & 3,8053 & 0,1167 & $7,48 \%$ & 0,0876 \\
$Y=a \cdot e^{b \cdot X}$ & 3,8747 & 0,0232 & $7,34 \%$ & 0,0885 \\
\hline
\end{tabular}




\begin{tabular}{crrrr}
\hline$Y=a+b \cdot \operatorname{Ln}(X)$ & 3,4043 & 0,6724 & $4,53 \%$ & 0,1874 \\
$Y=a \cdot X^{b}$ & 3,5854 & 0,1326 & $4,44 \%$ & 0,1918 \\
\hline \hline
\end{tabular}

Pelos P-valores dos modelos de regressão apresentados na Tabela 6 ( $\mathrm{P}$-valor $>0,05)$ nota-se que nenhum dos ajustes obtidos apresentou ser significativo, o que também é reforçado pelo valor pouco expressivo do coeficiente de determinação ajustado. A Figura 40 ilustra o modelo de regressão de melhor representatividade (linear), sendo evidenciada a não efetividade dos modelos testados pela dispersão dos dados.

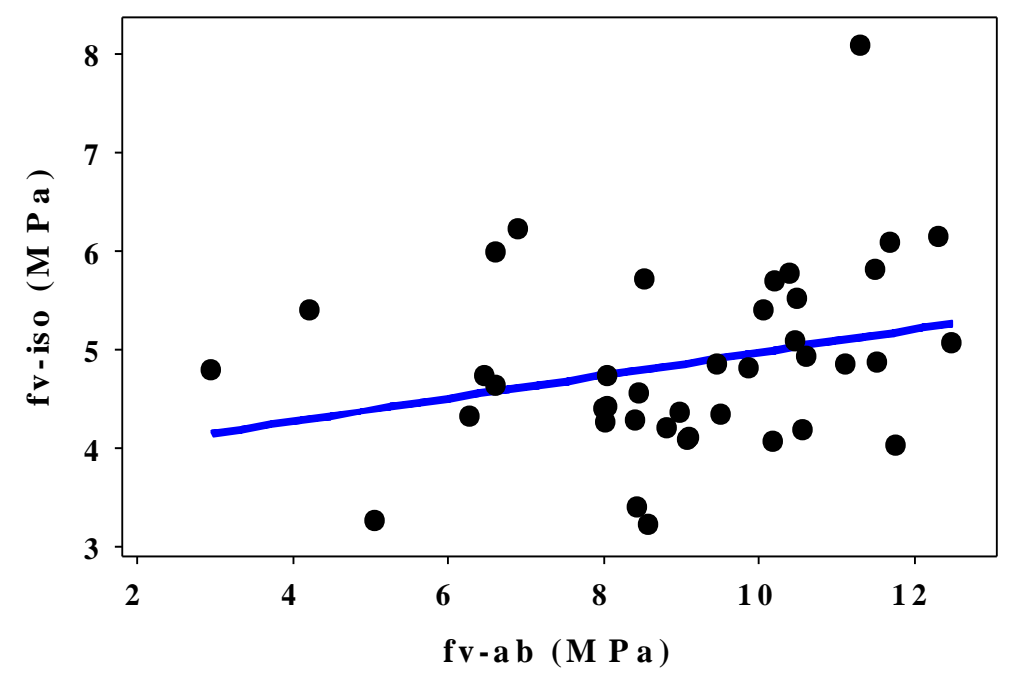

Figura 40: Modelos de regressão linear $\left[\left(\mathbf{f}_{\mathrm{v} \text {-iso }}=\mathbf{f}\left(\mathbf{f}_{\mathrm{v}-\mathrm{ab}}\right)\right]\right.$.

Eliminando os outliers, que consistiram em 9 pares de valores, o modelo de regressão linear ajustado $f_{v-i s o}=0,1953 \cdot f_{v-a b}+2,9027$ foi considerado significativo pela ANOVA (Pvalor $=0,000<0,05)$, e o coeficiente de determinação foi igual a 22,30\%. A Figura 41 apresenta o novo modelo de regressão linear. 


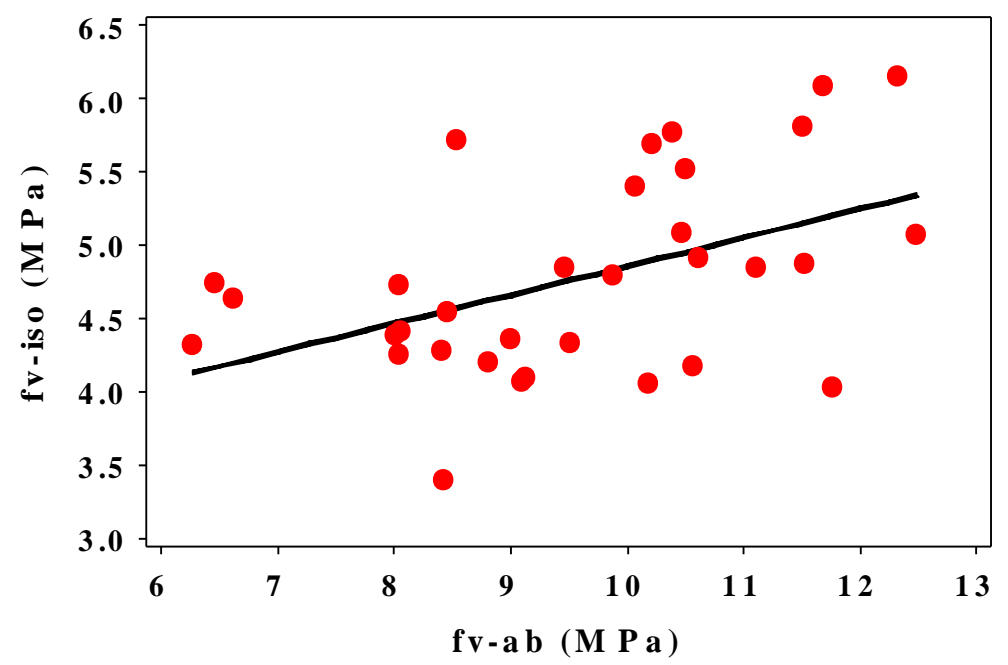

Figura 41: Modelos de regressão linear $\left[\left(f_{v-\text { iso }}=\mathbf{f}\left(f_{v-a b}\right)\right]\right.$ com a exclusão dos outliers.

Mesmo eliminados os outliers, o coeficiente de determinação do modelo $(22,30 \%)$ de regressão linear ainda sim explica muito pouco as variações nos valores da resistência ao cisalhamento pela norma ASTM ISO 13910:2005, o que indica a não relação direta dessas grandezas. 


\section{CONCLUSÕES E SUGESTÕES PARA TRABALHOS FUTUROS}

Conforme pode ser observado nos resultados, a resistência ao cisalhamento é bastante sensível ao método de ensaio. O método recomendado pelo documento normativo nacional ABNT NBR 7190:1997 considera ensaios para corpos de prova isentos de defeitos, ao passo que não é esta a realidade das madeiras disponíveis no mercado. É desejável que os métodos que utilizam elementos estruturais sejam incorporados ao documento brasileiro, de modo que os resultados obtidos possam ser utilizados em futuros projetos.

O desenvolvimento da triagem visual e mecânica, vai concentrar cada vez mais atenção na determinação e controle das características de resistência e da variabilidade em madeiras de reflorestamento e corpos de prova de dimensões de uso real .

Mesmo sendo utilizado um segundo corpo de prova proveniente da mesma tábua, o material estrutural ensaiado pelo método ASTM ISO 13910:2005, em toda maioria, obteve valores inferiores para a resistência ao cisalhamento em relação aos corpos de prova isentos de defeitos utilizados pelo documento normativo brasileiro ABNT NBR 7190:1997. Isto reflete sobre os valores característicos. Esta sensibilidade é bastante significativa, quando observa-se a madeira de Pinus utilizada, o valor característico calculado a partir do ensaio de cisalhamento em corpos de prova isentos de defeitos foi o dobro da resistência característica calculada nos ensaios de cisalhamento em corpos de prova estruturais.

Para continuidade da pesquisa a respeito do assunto, sugere-se:

- Aumentar o número de espécies consideradas, para maior abrangência da amostragem e, com isto, otimização dos resultados.

- Ampliar os estudos que venham a contribuir para mais detalhada avaliação da influência dos aspectos anatômicos nos valores numéricos que representam as propriedades da madeira.

- $\quad$ Considerar o tipo de ruptura dependendo da espécie utilizada.

- Simular numericamente a avaliação das tensões de cisalhamento nas peças. 


\section{REFERÊNCIAS BIBLIOGRÁFICAS}

ABRAF - ANUÁRIO ESTATíticO DA ABRAF. Associação Brasileira de Produtores de Florestas Plantadas. Brasília, p. 142. 2013. Acesso em: 16 junho 2016.

ALMEIDA, P. A. O. Estruturas de grande porte de madeira composta. Tese (Doutorado). Escola Politécnica da Universidade de São Paulo - PEF. EPUSP, 1990.

ASSOCIAÇÃO BRASILEIRA DE NORMAS TÉCNICAS. (1997). NBR 7190: Projeto de Estruturas de Madeira. Rio de Janeiro. Em revisão.

AUER, C.G.; JUNIOR, A.G.; SANTOS, A.F.; Cultivo do Pinus. Sistemas de Produção n5, 2005. Disponível em: <http://sistemasdeproducao.cnptia.embrapa.br> Acesso: 06 nov 2015.

BALLARIN, A.W.; LARA PALMA, H. A. Propriedades de resistência e rigidez da madeira juvenil e adulta de Pinus taeda L. Revista Árvore, Viçosa, v. 27, n. 3, p. 371-380, 2003.

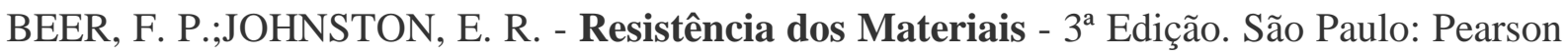
Makron Books, 1995.

BODIG, J.; JAYNE, B.A. (1982). Mechanics of wood and wood composites. New York, Van Nostrand Reinhold Company, 1982, 712p.

BORTOLETTO Jr, G.; ROCCO LAHR, A. F. - Aplicação da madeira de Pinus na construção civil - Madeira: Arquitetura e Engenharia. São Carlos, v. 2, n. 2, p.13-18, 2000.

BORTOLETTO Jr., G. (1993). Indicações para utilização da madeira de seis espécies e variedades de Pinus aplicada na construção civil. São Carlos. 119p. Dissertação (Mestrado) - Escola de Engenharia de São Carlos, Universidade de São Paulo.

BORTOLETTO JUNIOR G. (2008). Estudo de algumas propriedades físicas e mecânicas da madeira de Pinus merkusii. Scientia Forestalis, Piracicaba, v. 36, n. 79, p. 237-243.

CALIL JUNIOR, C.; LAHR, F. A. R.; DIAS, A. A. (2003). Dimensionamento de elementos estruturais de madeira. 1 ed. Barueri: Manole Ltda, 2003.

CARREIRA, M.R. Critérios para a classificação de peças estruturais de Pinus sp. Dissertação (Mestrado em Engenharia de Estruturas). EESC-USP, 2003.

CÉSAR, S.F. As estruturas Hauff de madeira no Brasil. São Carlos. 197p. Dissertação (Mestrado) - Escola de Engenharia de São Carlos, Universidade de São Paulo. 1991.

CHRISTOFORO, A. L.; PANZERA, T. H.; MOLINA, J. C.; ALMEIDA, D. H.; ROCCO, F. A. L. (2014). Determinação do módulo de elasticidade na compressão paralela às fibras da madeira: proposta de metodologia alternativa. Construindo, v. 6, p. 20-25, 2014. 
COPANT - COMISSÃO PANAMERICANA DE NORMAS TÉCNICAS. COPANT463: Metodo de determinación del cizallamiento paralelo al grano. $1972 \mathrm{~d}$.

CORADIN, V. T. R.; CAMARGOS, J. A. A. (2002). A estrutura anatômica da madeira e princípios para a sua identificação. Brasília: Instituto Brasileiro do Meio Ambiente e dos Recursos Naturais Renováveis - IBAMA; Laboratório de Produtos Florestais LPF, 2002.

COUTINHO, J. de S. Materiais de Construção 1: Madeiras. [S.1.: s.n., 1999]. Disponível em: < http://paginas.fe.up.pt/ jcouti/Madeiras\%2099.pdf >. Acesso dia: 29 set. 2015.

DENZLER, J. K.; GLOS, P.. Determination of shear strength values according to EN 408. Materials and Structures, v. 40, n. 1, p.79-86, 25 out. 2006.

EVANS, J. L.W.; SENFT, J. F.; GREEN, D. W. Juvenile wood effect in red alder: analysis of physical and mechanical data to delineate juvenile and mature wood zones. Forest Products Journal, v.50, n.7/8, p.75-87, 2000.

FACCIO, M. E. R.; Importância do gênero Pinus spp. para o setor madeireiro no Brasil. 2010. 61 p. Trabalho de conclusão de curso (Engenharia industrial madeireira) - Universidade Federal do Paraná, Curitiba, 2010.

GALVÃO, A. P. M.; JANKOWSKI, I. P. (1985). Secagem racional da madeira. São Paulo, Nobel, 1985, 112p.

GONÇALVES, R.; BARTHOLOMEU, A.. Avaliação do desempenho de ensaio não destrutivo em vigas de madeira de Eucalyptus citriodora e Pinus elliottii. Revista Brasileira de Engenharia Agrícola e Ambiental, [s.1.], v. 4, n. 2, p.269-274, 2000.

GONZAGA, A. L. Madeira: Uso e Conservação. IPHAN/MONUMENTA, Brasília, DF, 246 p, 2006.

HARA, M. M. et al. Resistência ao cisalhamento paralelo às fibras de madeira mediante esforço induzido por puncionamento. Engenharia e Construção Civil, Curitiba, v. 1, n. 2, p.40-53, jul. 2014.

ICIMOTO, F. H. Dormentes em madeira laminada colada de Pinus oocarpa. 2012. 122 f. Dissertação (Mestrado) - Curso de Ciência dos Materiais, Universidade de Sao Paulo - Usp, Sao Carlos, 2012.

IDO, H.; NAGAO, H.; KATO, H. (2010). Evaluation of shear strength of timber with fullscale block shear method. Paper presented at the 11th World Conference on Timber Engineering 2010, WCTE 2010, 1 513-520

INSTITUTO BRASILEIRO DE GEOGRAFIA E ESTATÍSTICA (IBGE). Mapa de biomas do Brasil. Rio de Janeiro, v.24, n. 2, 2010. Disponível em:<http://ibge.gov.br/home/estatistica/economia/pevs/2009/default.shtm> Acesso: 06 nov 2015

International Organization for Standardization (2005) ISO 13910, "Structural timber Characteristic values of strength-graded timber - Sampling, full-size testing and evaluation". Geneva, Switzerland. 2005 
KARLSEN, G. G. et al. Wooden strutures. Moscou, Mir, 1967.

MACHADO, N. C. de C. M. Variação dimensional da madeira devida ao seu comportamento higroscópico. Portugal, 2006. Disponível em: <http://repositorioaberto.up.pt/bitstream/10216/12372/2/Texto\%20integral.pdf>. Acesso dia: 30 set. 2014.

MOLINA, J.; CALIL JUNIOR, C. Sistema construtivo em wood frame para casas de madeira. Semina: Ciências Exatas e Tecnológicas, Londrina, v. 31, n. 2, p. 143-156, jul./dez. 2010.

MOLINA, J.C.; CALIL JUNIOR, C. Caracterização de clones e híbridos de eucaliptos com base na norma ABNT NBR 7190: 1997, Madeira: Arquitetura e Engenharia, v. 12, n.31, p. $1-8,2011$.

NAHUZ, M A. (2004). Atividades industriais com madeiras de Pinus - atualidades e desafios. São Paulo: Divisão de Produtos Florestais - IPT. Disponível em: $<$ http://www.ufsm.br/cepef/artigos/Atividades\%20industriais\%20com\%20madeiras\%20de\%2 0Pinus.pdf >. Acesso em: 03 abril 2016.

NAHUZ, M. A. R. Atividades industriais, usos e aplicações de madeiras no Brasil com ênfase em Pinus e Eucalyptus. In: OLIVEIRA, J. T. S.; FIEDLER, N. C.; NOGUEIRA, M. Tecnologias aplicadas ao setor florestal. Jerônimo Monteiro, 2007. p. 159-208.

NOGUEIRA, M. C. J. A. Indicações para o emprego de dezesseis espécies de eucalipto na construção civil. 1991. 116 p. Dissertação (Mestrado) - Departamento de Arquitetura e Urbanismo, São Carlos, 1991.

OLIVEIRA, J. T. da S. Propriedades Físicas e Mecânicas da Madeira In: OLIVEIRA, J. T. S.; FIEDLER, N. C.; NOGUEIRA, M. Tecnologias aplicadas ao setor madeireiro. Vitória, ES: Aquarius, p. 129-163, 2007.

OLIVEIRA, J. T. S.; DELLA LUCIA, R. M. ; VITAL, B. R. Estudo das propriedades físicas e tecnológicas da madeira da pindaíba (xylopia sericea St. Hill.). III. Propriedades Mecânicas. Revista Árvore, 12(2) : 129-133, 1988.

RIYANTO, D. S.; GUPTA, R. (1998). A comparison of test methods for evaluating shear strength of structural lumber. Forest Products Journal, 48(2), 83-90.

RODRIGUES, R. A. D. Variabilidade de propriedades físico-mecânicas em lotes de madeira serrada de eucalipto para a construção civil. 2002. 76 f. Dissertação (Mestrado) -, Escola Superior de Agricultura "Luiz de Queiroz", Universidade de São Paulo, Piracicaba, 2002.

SALES, A. Proposição de classes de Resistência para Madeira. 223 f. Tese (Doutorado) Curso de Engenharia de Construção Civil, Universidade de São Paulo, São Paulo, 1996.

SANDOZ, J. (2003). Forest, timber and environment. 
SANTINI, E. J.; HASELEIN, C. R.; GATTO, D. A. Análise comparativa das propriedades físicas e mecânicas da madeira de três coníferas de florestas plantadas. Ciência Florestal, Santa Maria, v. 10, n. 1, p.85-93, 2000.

SERPA, P.N.; VITAL, B.R. Propriedades da madeira de Pinus elliotti. Revista da Madeira, Curitiba, v. 15 n. 89, 2005. Disponível em: <http://www.remade.com.br/pt/revista_materia.php edição $=89 \& i d=735>$ Acesso em: 15 maio 2016.

SERVIÇO FLORESTAL BRASILEIRO (SFB). Florestas do Brasil em resumo 2013. Brasília, 2013. 39 p. Disponível em: <http://www.mma.gov.br/estruturas/sfb.pdf>. Acesso em: 15 nov. 2015.

SHIMIZU, J. Y. Pinus na silvicultura brasileira. Colombo: Embrapa Florestas, 2008. 223 p.

SILVA, C.; BRANCO, J. M.; LOURENÇO, P. B. MLCC na construção em altura. $4^{\text {o }}$ Congresso Nacional da Construção. Coimbra, Portugal: [s.n.]. 2012. p. 12.

SNIF. Sistema Nacional de Informações Florestais, 2016. Disponível em: <http://www.florestal.gov.br/snif/> Acesso em: 11 maio 2016.

SPIB - Southern Pine Inspection Bureau - Standard grading rules for southern pine lumber. Pensacola, Fla. 1994

STAMATO, G. C. (1998). Resistência ao embutimento da madeira compensada. Dissertação (Mestrado). Escola de Engenharia de São Carlos, Universidade de São Paulo.

TRIANOSKI, R.; MATOS,J.L.M.; IWAKIRI,S.; PRATA,J.G. - Avaliação das propriedades mecânicas da Madeira de species de Pinus Tropicais. Scientia Forestalis, Piracicaba, v. 42, n. 101, p. 21-28, mar. 2014

VALVERDE, S.R. et al. O comportamento do mercado da madeira de eucalipto no Brasil. Revista Biomassa e energia, v. 1, n. 4. p. 393-403, 2004.

VILLAÇA, S. F.; GARCIA, L. F. Taborda. Introdução à teoria da elasticidade. 3. ed. Rio de Janeiro: Coppe/UFRJ, 1998.

WHITE, ROSS. Wood and timber condition assessment manual: second edition. General Technical Report FPLGTR-234, 2014 